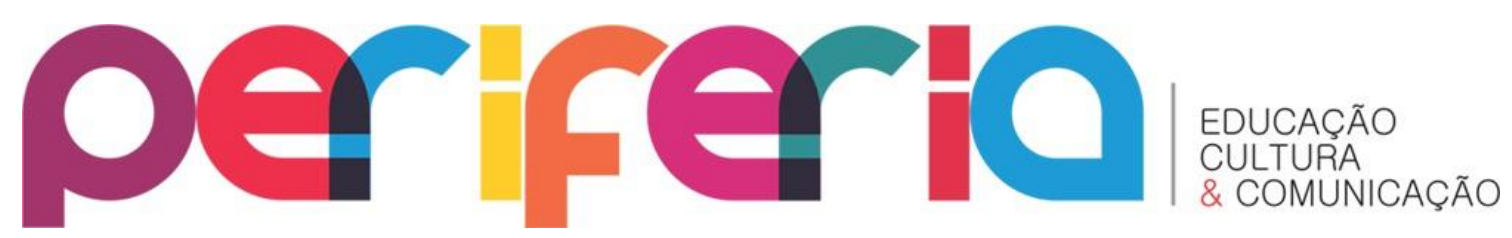

\title{
O TERREIRO DE CANDOMBLÉ MANSO GONGOMBIRA DINHANGA NGINJI COMO ESPAÇO DE EDUCAÇÃO NÃO ESCOLAR
}

Ailma da Silva Conceição ${ }^{1}$

Eduardo Oliveira Miranda²

\section{Resumo}

A presente produção textual tem rebatimento na história de vida de uma mulher negra, candomblecista e pedagoga que vislumbra nas suas memórias as potencialidades para repercutir a efetivação da Lei $10.639 / 03$ no seu ato de mediar a formação dos seus educandos. Sendo assim, o artigo tem como objetivo identificar como os espaços não escolar que compõem um terreiro de Candomblé Manso Gongombira Dinhanga Nginji favorece na construção da identidade negra das crianças que convivem em suas territorialidade. Acreditando nas diversas potencialidades de ensino que existem dentro de um terreiro de candomblé, para tal, utilizamos a metodologia das Narrativas Autobiográficas para alcançar os dados necessários. Verificando através de relatos como essas crianças de terreiro aprenderam os valores indenitários afrobrasileiros. A importância de estudar esse tema tem como intuito identificar fatores que encontramos nesse espaço não escolar que contribui para que as crianças constituam seus valores indenitários da cultura afro-brasileira.

Palavras-Chave: Educação Étnica-Racial, Educação não formal/escolar, Terreiro de Candomblé.

\section{THE TERREIRO DE CANDOMBLÉ MANSO GONGOMBIRA DINHANGA NGINJI AS AN AREA OF NON-SCHOOL EDUCATION}

\begin{abstract}
The present textual production has a rebound in the life history of a black woman, a candomblecist and pedagogue who glimpses in her memories the potentialities to reflect the effectiveness of Law 10.639 / 03 in her act of mediating the formation of her students. Thus, the article aims to identify how the non - school spaces that make up a Candomblé Manso Gongombira Dinhanga Nginji terreiro favors in the construction of the black identity of the children that coexist in their territoriality. Believing in the diverse teaching possibilities that exist within a candomble terreiro, for this, we use the methodology of the Autobiographical Narratives to reach the necessary data. Checking through reports how these terreiro children learned the Afro-Brazilian indent values.

\footnotetext{
${ }^{1}$ Pedagoga formada pela Universidade Federal da Bahia - UFBA. E-mail: s.ailma@yahoo.com.

${ }^{2}$ Doutor em Educação pela Universidade Federal da Bahia - UFBA. Professor Assistente da Universidade Estadual de Feira de Santana - UEFS, lotado no Departamento de Educação. E-mail: eduardomiranda48@gmail.com
} 


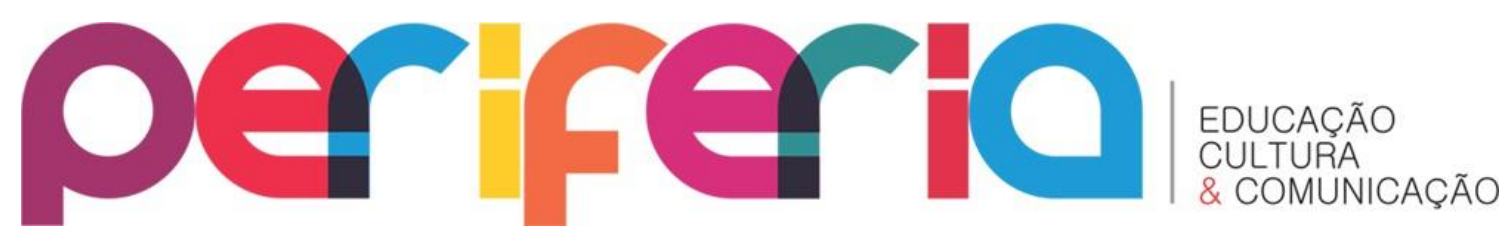

ISSN:1984-9540

DOI: $10.12957 /$ periferia.2020.36046

The importance of studying this theme has the purpose of identifying factors that we find in this non-school space that contribute to children's values of the Afro-Brazilian culture.

Keywords: Ethnic-Racial Education, Non formal / school education, Terreiro de Candomblé.

\section{EL TERREIRO DE CANDOMBLÉ MANSO GONGOMBIRA DINHANGA NGINJI COMO ESPACIO DE EDUCACIÓN NO ESCOLAR}

\section{Resumen}

La presente producción textual tiene rebatimiento en la historia de vida de una mujer negra, candomblecista y pedagoga que vislumbra en sus memorias las potencialidades para repercutir la efectividad de la Ley 10.639 / 03 en su acto de mediar la formación de sus educandos. Siendo así, el artículo tiene como objetivo identificar cómo los espacios no escolar que componen un terreiro de Candomblé Manso Gongombira Dinhanga Nginji favorece en la construcción de la identidad negra de los niños que conviven en su territorialidad. Creyendo en las diversas posibilidades de enseñanza que existen dentro de un terreiro de candomblé, para ello, utilizamos la metodología de las Narrativas Autobiográficas para alcanzar los datos necesarios. Verificando a través de relatos como esos niños de terreiro aprendieron los valores indenarios afrobrasileños. La importancia de estudiar este tema tiene como objetivo identificar factores que encontramos en ese espacio no escolar que contribuye a que los niños constituyan sus valores indenarios de la cultura afro-brasileña.

Palabras clave: Educación Étnico-Racial, Educación no formal / escolar, Terreiro de Candomblé.

\section{INTRODUÇÃO}

Não sou descendente de escravos. Eu descendo de seres humanos que foram escravizados. - Makota Valdina.

A minha história de vida está intimamente relacionada com o terreiro de candomblé, espaço onde cresci e aprendi como conviver e a respeitar todos independente da religião, convivo diariamente com a cultura afro-brasileira que é de grande importância para ampliação dos meus conhecimentos que favoreceu na construção da minha identidade negra. 


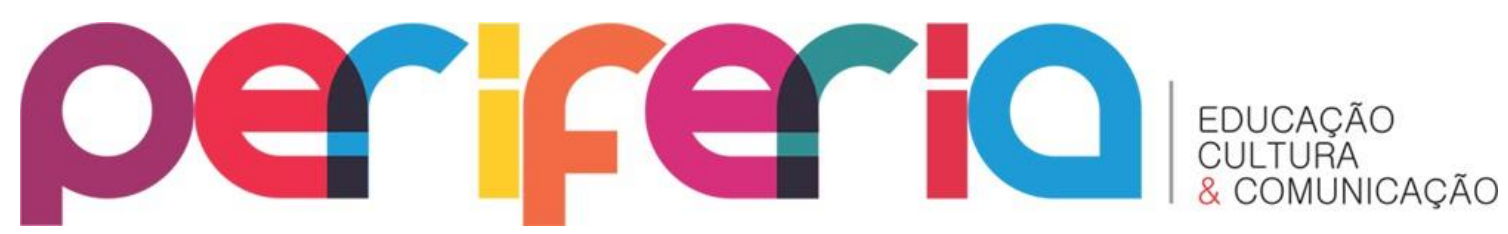

ISSN:1984-9540

DOI: $10.12957 /$ periferia.2020.36046

Por ter sido uma criança de terreiro, que participou ativamente desse processo da construção da identidade negra, presenciei dentro das escolas como os terreiros de Candomblé e as crianças que convivem nesse local são alvo de discriminação e preconceitos diários. Por isso, aprendi que não devemos naturalizar a condição do negro com a perpetuação da expressão escravo, mas realinhar as ideias e estabelecer que somos descendentes de seres humanos que sofreram com o processo de colonização e das diásporas africanas, como elucida Makota Valdina ${ }^{3}$.

Então, o interesse pelo tema deste artigo surgiu ao presenciar dentro das salas de aula em que me encontro inserida, as falas estereotipadas que surgem de alunos e de muitos profissionais da educação sobre a cultura afro, sobre o ambiente em que são realizados seus cultos, em relação as divindades africanas, sempre como um local ignorado e que não possuí nada de positivo. A escolha pelo tema estudado tem como problemática apresentar como o terreiro de candomblé Manso Gongombira Dinhanga Nginji ${ }^{4}$ utiliza seus espaços não escolares para favorecer a construção da identidade negra nas crianças. Com o objetivo geral: compreender o processo de construção da identidade negra dentro dos terreiros.

A Manso Gongombira está localizada no bairro da Mata Escura, na capital baiana , Salvador. Fundada em 2013, pelo Ttata Rya Nkise NHUNKABUKILA, uma casa majoritariamente composta por ex crianças que foram criadas e educadas dentro do terreiro matriz o Bate folha ${ }^{5}$, o qual cedia seus espaços para muitas

\footnotetext{
${ }^{3}$ Valdina de Oliveira Pinto, mais conhecida como Makota Valdina, (Salvador, 15 de outubro de 1943) é uma educadora, líder comunitária e religiosa brasileira, militante da liberdade religiosa, como porta-voz das religiões de matriz africana, bem como dos direitos das mulheres e da população negra. Professora aposentada da rede pública municipal de Salvador, foi membro do Conselho Estadual de Cultura da Bahia. Exerce a função religiosa de Makota (assistente de mãe de santo) do Terreiro Tanuri Junsara, no Engenho Velho da Federação, bairro em que nasceu e cresceu.

${ }^{4} \mathrm{~A}$ tradução: Antigo caçador da beira do rio.

5 O terreiro do Bate Folha (MANSO BANDUQUENQUÉ), esse é o nome da casa regida por KAIANGO, nkise a qual o terreno foi doado para a sua fundação no ano de 1916, está localizado na rua Travessa São Jorge, no bairro da Mata Escura. O terreiro do Bate Folha foi fundado pelo Tata Manoel Bernardino, possui uma extensa área de mata atlântica preservada e tombada pelo IPHAN em 10/10/2003, considerado um dos maiores e mais velhos terreiros do Brasil, hoje com 102 anos de resistência e perpetuação da cultura afro- religiosa, com destaque para a nação Congo/Angola.
} 


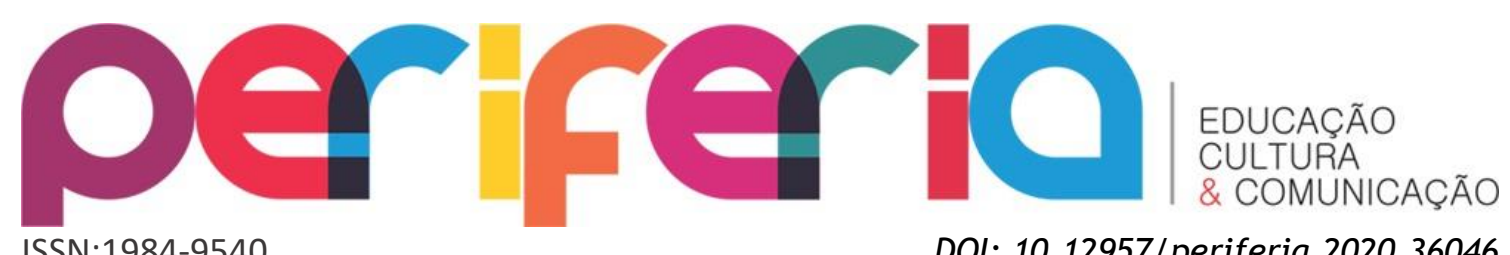

ISSN:1984-9540

DOI: $10.12957 /$ periferia. 2020.36046 famílias construírem seu lar, a Manso Gongombira é construída nesse espaço que foi cedido aos pais do tata Rya Nkise em um momento em que sua família perdeu a casa em que morava devido a uma chuva.

Por muitos anos vivencio diversas cenas relatadas e assistidas dentro das unidades escolares, e por medo da reação dos outros e de ser excluída do convívio com meus colegas, tive que esconder a minha doutrina religiosa e meus adereços por muito tempo. Essas cenas de preconceitos, e intolerância religiosa não se restringiu aos muros das escolas do ensino médio e fundamental, foi além, chegando até os muros da universidade.

Toda extensão de um terreiro de candomblé é de grande importância para todos que convivem nessa área, seja crianças, jovens ou adultos, para compreender as potencialidades educativas desse local é necessário nos despir de antigos preconceitos, que por anos nos acompanham e encontra-se incutido na nossa sociedade em relação a cultura afro brasileira.

A Educação Afro-Brasileira faz parte da minha identidade como mulher negra e afrodescendente, que foi criada e educada nos espaços não escolar de um recinto de Candomblé. Durante todo o tempo de convívio nesse local havia a preocupação dos mais velhos da casa em orientar, educar, e transmitir tudo sobre a nossa cultura, ensinamentos dados a todas as crianças, com o intuito de manter e preservar a nossa cultura e para que pudéssemos conhecer a real história do nosso povo.

Somos ensinados a não perpetuar o preconceito com o outro, não aceitar nenhum tipo de discriminação, os ensinamentos recebidos diariamente nos terreiros contribui para uma relação de respeito, e fortalece a importância dos valores étnicos e morais e aceitação das diferenças como afirma Guedes, (2002, p. 43): "O terreiro de candomblé é um local em que se ensina o antirracismo e o humanismo do que precisamos todos os dias".

A conduta que cada um terá fora dos espaços do terreiro é uma das maiores preocupações dos mais velhos que compõe o núcleo da casa. No cotidiano as crianças vão sendo educadas e preparadas para aprenderem a trabalhar em grupo, respeitando um ao outro, esse processo educativo dentro dos terreiros motivam as crianças a interagir com todos igualmente.

Periferia, v. 12, n. 3, p. 268-301, set./dez. 2020 


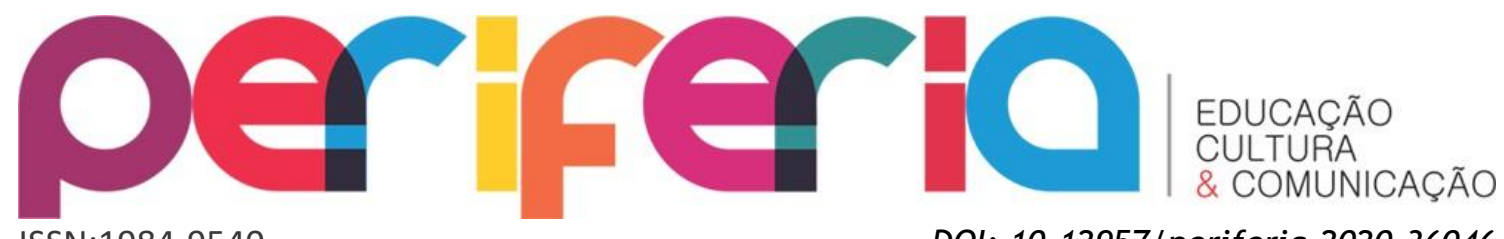

ISSN:1984-9540

DOI: $10.12957 /$ periferia.2020.36046

Asseguro que esse território que convivo possuem grandes valores educacionais, sou fruto desse espaço, fui/sou uma “criança de terreiro", foi lá que aprendi a lê e a escrever com pessoas que não possuía nenhuma formação acadêmica, mas dispõe de formação e experiência de vida, com a preocupação e obrigação de alfabetizar todas as crianças. Aprendi a valorizar a minha cor, a minha cultura, o meu povo, respeitar o próximo e valorizar individualmente cada um, esses ensinamentos contribui positivamente na construção da identidade negra, essa questão foi sim o estimulo para desenvolver esta pesquisa.

É relevante reconhecer e valorizar as extensões territoriais não escolar de um terreiro de Candomblé como um local que possui potencialidades educativas, que contribui para o conhecimento e realimentação da cultura AfroBrasileira, procurei expandir meus conhecimentos e descrever como contribui para a formação de um ser crítico.

Metodologicamente o trabalho realizado caracteriza-se como uma pesquisa de Narrativa Autobiográfica, a escolha por essa metodologia tem como objetivo a construção da minha história de vida, possibilitando uma reflexão crítica de todo o processo de formação educacional e autoconhecimento da minha existência. A narrativa autobiográfica permite ao autor uma ligação direta com a pesquisa e possibilita a utilização de infinitas fontes, por isso, utilizo as memórias e narrativas do processo educacional dos mais velhos do terreiro de candomblé. As narrativas são definidas por Fernandes (2011, p.127) como:

As narrativas são formas mais ou menos organizadas, escritas ou orais, de expressão do pensamento humano; de algum modo, elas dão sentido e significado a acontecimentos (experiências) que se viveram, que se vivem ou que se esperam vir a viver. Neste sentido, pode dizer-se que as narrativas são de natureza eminentemente pessoal e subjetiva.

Esse trabalho de reativar lembranças do passado, está diretamente ligado aos sujeitos da pesquisa que eram crianças que conviviam no terreiro e 


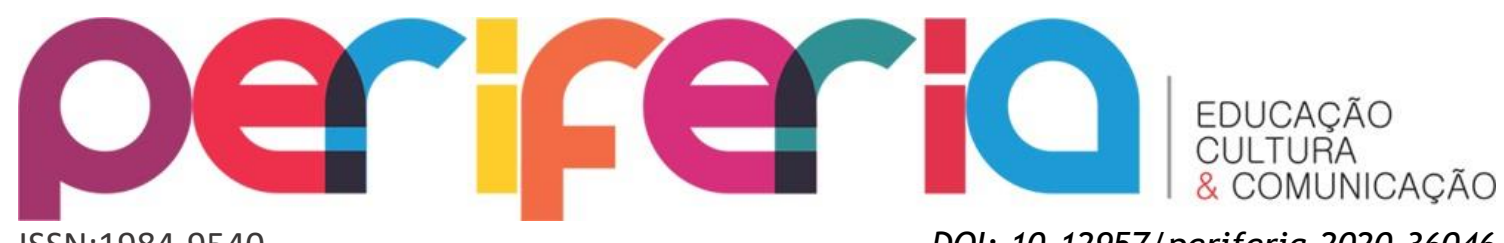

ISSN:1984-9540

DOI: $10.12957 /$ periferia.2020.36046 hoje são consideradas os mais velhos que compõem a casa e teve seu processo educacional iniciático dentro de um terreiro de candomblé, no convívio diário.

A narrativa autobiográfica é muito utilizado nos dias atuais por favorecer ao pesquisador um envolvimento direto com a pesquisa, requerer uma observação e escuta atenta. Essa é uma oportunidade que tenho em reescrever as histórias vividas, proporcionando um diálogo constante com as minhas memórias, para melhor entendimento desses relatos é preciso compreender que:

Quando um pessoa relata os fatos vividos por ela mesma, percebe-se que reconstrói trajetória percorrida dando-lhe novos significados. Assim, a narrativa não é a verdade literal dos fatos, mas, antes, é a representação que deles faz o sujeito e, dessa forma, pode ser transformadora da própria realidade (CUNHA, 1997, p.2).

Nesse direcionamento será explorado como os espaços não escolares de um terreiro de candomblé contribui de forma positiva para a construção da identidade das crianças negras e adeptas da cultura do povo de Santo, sendo capaz de se reconhecer em qualquer território que esteja inserida como sujeito participante da sua história.

Escolhido e delimitado o tema, chegou à hora de eleger os teóricos responsáveis por fundamentar as nossas investigações. Dentre os referenciais, destaco Stela Guedes Caputo (2012) que através do seu trabalho Educação nos Terreiros apresenta as diversas formas educacionais que existem nos espaços não escolares dos terreiros, os conflitos religiosos, a negação da religião de matriz africana encontrada pelas crianças do terreiro dentro das escolas. Através da contribuição de Caputo foi mais acessível compreender que as crianças que habitavam o terreiro estudado por ela eram conduzidas a negar sua religião dentro dos espaços formais de educação, como é muito bem descrito por Caputo (2012, p.197): “As crianças são obrigadas a esconder os artefatos religiosos, os preceitos do culto, a fé. Isso acontece em diversos espaços, mas de acordo com os depoimentos, a escola é o pior deles". 


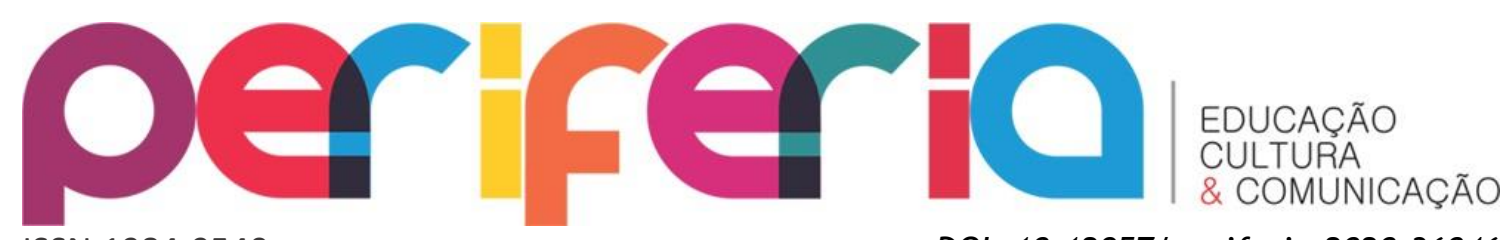

ISSN:1984-9540

DOI: $10.12957 /$ periferia.2020.36046

Em seguida, discorro sobre oralidade e memórias e a importância e manutenção da cultura oral, reativar lembranças pessoal e coletiva, para melhor compreensão que a educação pode ser transmitida em qualquer espaço. Trago o trabalho de Vanda Machado (2002) Vivências e Intervenções Pedagógicas, realizado dentro do terreiro Ylê Afonjá, em sua obra apresenta as infinitas possibilidades educacionais que podem ser exploradas em uma escola que habita os espaços de um terreiro de candomblé, como um local rico de ensinamentos que contribui para que as crianças possam valorizar e se identificar com a cultura afro-brasileira.

Para ampliação desse trabalho dentro das salas de aula, é necessário a reformulação do nosso currículo, inserir atividades que dê visibilidade ao povo negro e enalteça a cultura Afro- brasileira, hoje obrigatório e está embasado na lei $\mathrm{n}^{\circ} 10639 / 03$, nesse momento evidencio a obra de Nilma Lino Gomes (2012) Relações Étnico-racial, educação e descolonização dos currículos. A autora firma a necessidade de se modificar os currículos e que essa modificação possa abranger a todas as redes de ensino, intensificando a afirmativa que a escola é o local que mais se reproduz e perpetua o preconceito ao negro. Para ampliar o debate, apresento relatos de alguns participantes da entrevista do processo de superação do racismo e como influenciam as crianças de hoje na formação da sua identidade negra. Sobre a Superação do racismo busquei apoio em Munanga (1986), que em sua obra Superando o racismo na escola, somos apresentados as mais variadas formas de reprodução do racismo e do preconceito que acontecem dentro das escolas, a omissão de muitos profissionais, que é justificado pela falta de segurança que nos deixam muito vulneráveis. Em sua obra apresenta exemplos de atividades que podem auxiliar aos profissionais de todas as áreas da educação a trabalharem de forma positiva a imagem do negro. Nesse direcionamento que analiso como os espaços não escolares do terreiro contribui de forma positiva para que as crianças que habitam esse local construa sua identidade como crianças negras e adeptas da cultura afro brasileira.

Periferia, v. 12, n. 3, p. 268-301, set./dez. 2020 


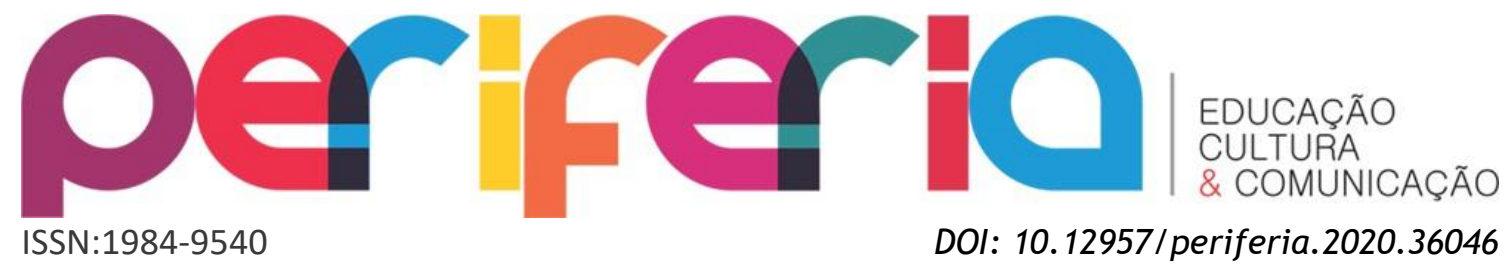




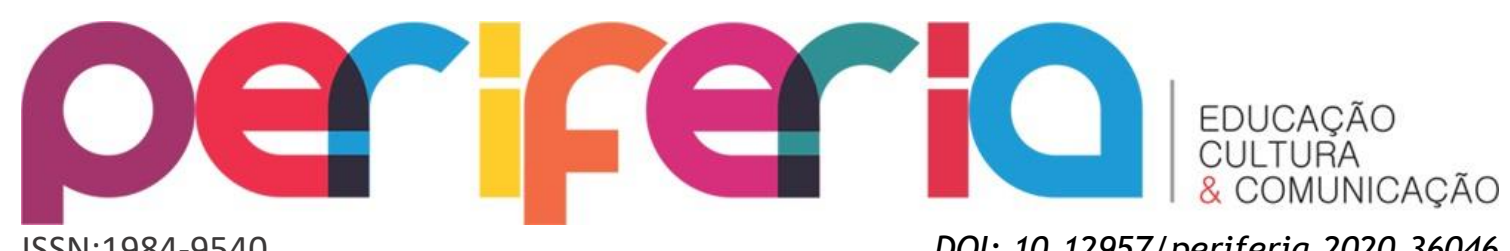

ISN:1984-9540

DOI: $10.12957 /$ periferia. 2020.36046

Terreiro como espaço educativo não formal/não escolar

Para prosseguir o nosso diálogo preciso explanar como cheguei aos espaços de um terreiro de candomblé, pois é o princípio do meu processo educacional. A convivência em um terreiro de candomblé teve início com minha bisavó Roberta da Silva Conceição ${ }^{6}$, conhecida pelo seu nome africano Batuilo que era filha de santo da casa, em 1959 a pedido de seu Tata de Nkise que dirigia a casa na época (1949 - 1965), o senhor Antônio, de nome africano Bandanguame trouxe sua neta Marta da Silva Conceição, que é a minha mãe, com 7 anos de idade.

$\mathrm{Na}$ época era muito comum os apadrinhamento com pessoas que possuíam uma melhor condição financeira. Trazia as crianças do interior do estado da Bahia para morar em Salvador e realizar os trabalhos domésticos, prática ainda muito corriqueira nos dias atuais, o que caracteriza a exploração do trabalho infantil. 0 terreiro que minha avó frequentava era muito grande e necessitava de muita mão de obra, minha mãe morava no interior e a vida era muito difícil, o único meio de sobrevivência era por meios de plantações.

Após minha avó ser iniciada, decide morar no terreiro e se muda com seus filhos, onde ganhou uma casa que ficava nos fundos do terreiro e com seus filhos segue uma nova trajetória de vida, assim se deu a chegada da minha mãe ao terreiro do Bate Folha com 7 anos de idade, não sabia ler e nem escrever, foi alfabetizada pela senhora Marieta, nome africano Kisuxino também filha de santo da casa, com o objetivo de alfabetizar as crianças que moravam no terreiro e aos entornos dele, montou uma escolinha, era tudo bem simples e improvisado. Kisuxino tinha grande aptidão para o ensino, mais ninguém sabia o seu grau de escolaridade. Em meios as histórias contadas por minha mãe, a mesma afirma que aprendeu a ler, a escrever, a bordar, costurar, e a cozinhar dentro do próprio terreiro, minha mãe nunca frequentou uma escola formal. No terreiro, casou-se, teve 4 filhos todos receberam os primeiros ensinamentos nesse mesmo espaço.

\footnotetext{
${ }^{6}$ Minha bisavó iniciada no Terreiro do Bate Folha, recebeu a digina (nome africano designado pelo nkise) de Batuilo, filha do Nkise Kavungo (Obaluae).
} 


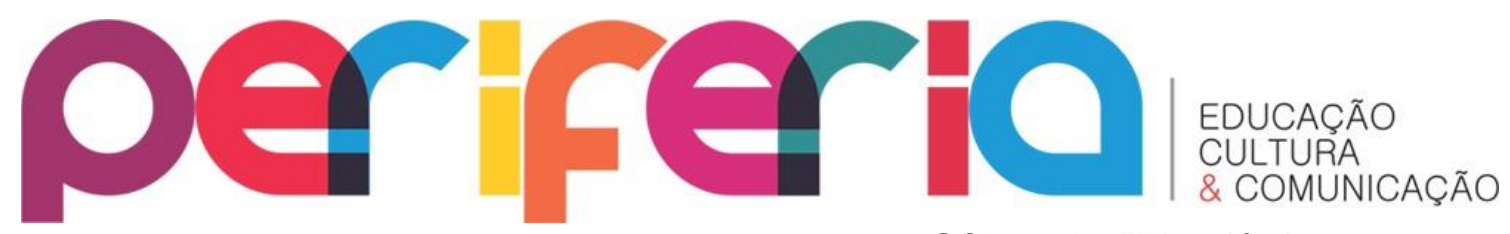

ISSN:1984-9540

DOI: $10.12957 /$ periferia. 2020.36046

Minha mãe nunca teve contato com uma escola formal, devido a evolução dos tempos os seus filhos seguiram outros caminhos, inicialmente todos foram criados, educados e alfabetizados por filhos de santo da casa, e só anos mais tarde fomos inseridos a um espaço educacional formal. Para ser inserida a esse espaço, era necessário passar por uma avaliação diagnóstica com a finalidade em identificar em que nível de aprendizagem me encontrava. Tal avaliação foi necessária porque não possuía nenhum histórico escolar que comprovasse o nível de escolaridade. Fui direcionada ao grupo da $3^{\circ}$ série, ao chegar na escola já sabia ler e escrever, conhecia parte da história e origens do meu povo, a qual me foi transmitida através da oralidade, das potencialidades e contribuições de uma cultura rica que favoreceu para a história da nossa cidade, capital baiana.

História essa constituída pelos escravizados oriundos de diversas localidades da África, e com eles a cultura africana que envolve um conjunto de manifestações como danças, idiomas, artes, culinárias, tecnologias, epistemologias, músicas, e representatividades que compõem um terreiro de candomblé.

O culto as nossas ancestralidades era algo proibido, tudo que pertencia a cultura africana começa a sofrer grandes perseguições, que perduraram por longos anos, os nossos direitos foram negados, fomos perseguidos, massacrados e sucumbidos por essa sociedade desigual por muitos anos. A perseguição ao Candomblé se intensificou a partir da década de 1930 com a perspectiva do processo de embranquecimento como estratégia para tentar modificar o perfil da população que na época era predominantemente negra, como afirma Marcos Aurélio Luz (2008) em sua obra Cultura negra em tempos pós modernos, quando diz que:

Para alimentar o projeto de europeização de bases industriais, juntamente com o "bota abaixo" das cidades do fim do período colonial, se procurava pouco a pouco botar abaixo não só edificações institucionais coloniais, mas também transformar o perfil da população, especialmente, a de aborígines, africanos e seus descendentes, para abrir espaço as novas relações de produção, tendo como agentes os imigrantes europeus (LUZ, 2008, p. 24).

Para silenciar a nossa história, nas escolas era apresentado uma única

Periferia, v. 12, n. 3, p. 268-301, set./dez. 2020 


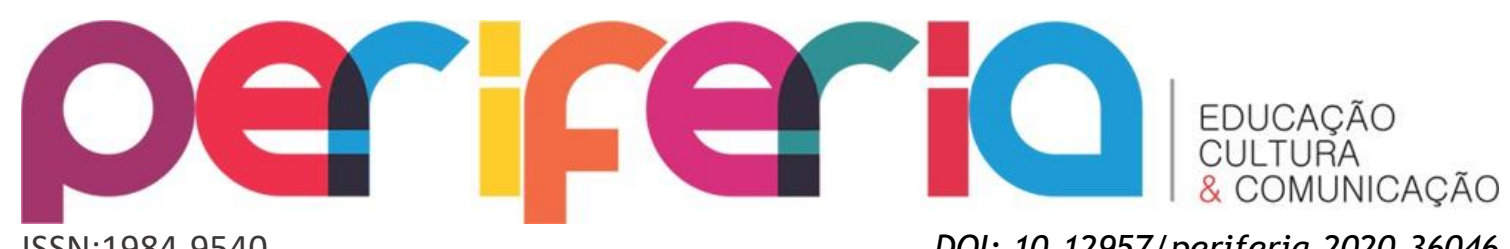

ISSN:1984-9540

DOI: $10.12957 /$ periferia.2020.36046 cultura, bem raramente no mês de novembro ouvia-se algo sobre a cultura afro, tudo muito superficial, e aos poucos compreendia o distanciamento que existia entre o que havia aprendido no terreiro com o ensino no espaço formal de educação, era notório a negação a tudo que se remetia à cultura do negro.

Existia um entendimento que uma cultura voltado exclusivamente de negros manchava a cidade. Então, nessa época intensificou uma perseguição sistemática a qualquer movimento que tivesse ligação a cultura do afrodescendente, muitos terreiros foram fechados, com seus objetos quebrados e apreendidos proibindo o culto a nossos deuses, essa perseguição é muito bem retratada na obra Presença e tradição negra na Bahia: “Qualquer casa de culto negro, para existir na Bahia, precisava registrar-se na Delegacia de Jogos e Costumes, como qualquer casa de diversão - noite de baile ao som dos ataques" (TAVARES, 2009, p.25).

A cultura afro brasileira é sinônimo de perseverança e resistência, nossa história sempre foi marcada por lutas que permanece até os dias atuais. Para intensificar esse silenciamento surgem os estereótipos que negativam os valores africanos, e para Munanga (1986), os estereótipos geram os preconceitos, que se constituem em um juízo prévio a uma ausência de real conhecimento do outro.

Essa falta de conhecimento do outro, intensifica e propaga cada vez mais em todas as esferas da sociedade, principalmente nos espaços escolares, que repercute de forma negativa sobre as crianças negras, influenciando diretamente no seu modo de pensar e de se identificar: "A escola como aparelho ideológico do estado, na sua pratica, tende a ignorar os valores culturais negros, seu universo simbólico, incutido nas crianças os padrões e estereótipos das ideologias do branqueamento” (MACHADO, 1990, p.57).

Qual criança irá desejar se reconhecer como negra diante das imagens estereotipadas que são representadas? Que criança irá se apresentar como da religião de matriz africana em um espaço que não favorece a sua cultura? Quem irá se identificar ao abrir um livro didático e vê a imagem do seu semelhante sendo humilhado ou aprisionado a uma corrente, realizando sempre trabalhos 


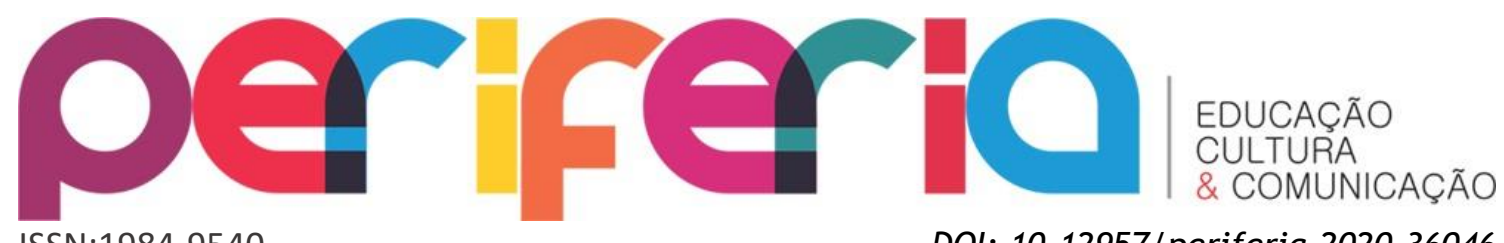

ISSN:1984-9540

DOI: $10.12957 /$ periferia. 2020.36046 menos favorecidos? Quando criança sonhamos a cada instante e cada sonho sempre é com algo positivo que desejamos.

As crianças negras não se identificam nos ambientes escolares, como mulher negra, logo percebi que nos espaços escolares quando se falavam em cultura afro-brasileira nada mais era do que apenas um discurso apropriado. Em nenhum momento da trajetória escolar me senti representada quando o assunto era a cultura negra. Era tudo tão distante e ao mesmo tempo desentoado da realidade em que vivo. Muitas vezes escutava tudo calada e nunca permiti ser influenciada, isso por que sempre tive orientações e saberes diários, em que presenciava e ouvia fatores positivos e ricos da nossa cultura.

No espaço formal de educação sofri e sofro muitas discriminações direta e indiretamente, seja com as representações nos livros didáticos sobre o meu povo, nas caricaturas demasiadas por alguns professores que não sabem como trabalhar a diversidade cultural existente em nossa cidade, é um descaso visível ao se trabalhar com a cultura afro brasileira, é notório o distanciamento que existe entre o que a Lei propaga e o que vivemos diariamente nas redes de ensino, essa discursão é reforçada por Munanga (2005, p. 15) quando afirma que:

No entanto, alguns professores, por falta de preparo ou por preconceitos neles introjetados, não sabem lançar mão das situações flagrantes de discriminação no espaço escolar e na sala como momentos pedagógicos privilegiados para discutir a diversidade e conscientizar seus alunos sobre a importância e a riqueza que ela traz à nossa cultura e a nossa identidade nacional.

É muito triste quando nós, filhos e frutos de um terreio de Candomblé, estamos em um espaço que apresenta-se como laico e escutamos coisas do tipo: “Macumba? Isso é coisa do Diabo". Não somos frutos do diabo, somos frutos de seres humanos que tem a liberdade de cultuar seu povo, sua origem e sua tradição, que devem ser respeitados por todos e em todos os espaços igualmente.

Hoje em diversos momentos podemos observar os olhares e relatos quando é presenciado uma pessoa da religião de matriz africana trajada, é notório como muitas pessoas têm reações diversas. Na graduação esse 


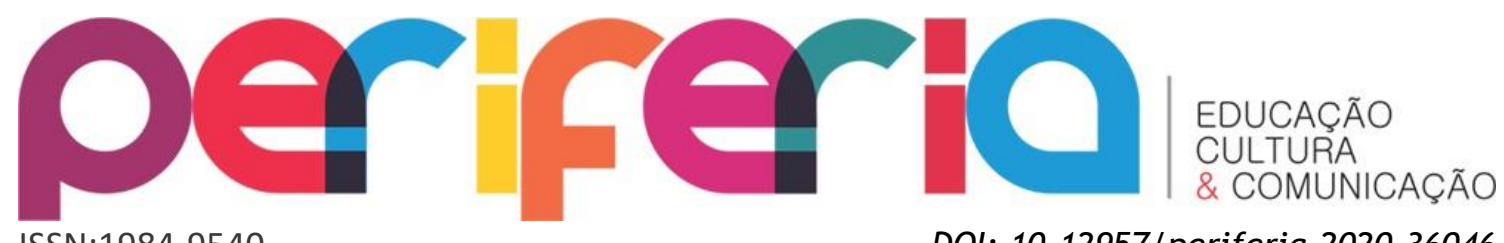

ISSN:1984-9540

DOI: $10.12957 /$ periferia.2020.36046 comportamento não é diferente, essa discriminação surge nas diversas esferas da universidade que perpassa por professores, alunos, funcionários. Isso se dá devido ao nosso currículo de ensino e aprendizagem, que nos aprisionam com os desvios históricos, a ausência de conhecimento teórico para se trabalhar adequadamente a cultura afro-brasileira e africana.

No ingresso ao ensino superior no ano de 2012, logo verifiquei que a grade curricular não disponibilizava nenhum componente que trabalhasse a cultura afro-brasileira de forma obrigatória, anos mais tarde surge um componente para ser trabalhado a História e Cultura Africana e Afro-brasileira, sendo ofertada de forma optativa, não posso negar foi frustrante e as inquietações e indagações só aumentavam: Em uma faculdade de Educação por que não trabalhar a cultura afro de forma obrigatória? Como seremos profissionais capacitados para articular a diversidade cultural? $\mathrm{E}$ as indagações permaneceram sem respostas, bem raramente ouvia falar algo sobre a cultura afro, de forma bem suscita.

Anos se passaram dentro da faculdade de Educação e comecei a perceber que o preparo que buscava para trabalhar com as diversidades culturais, só iria acontecer na prática, fora dos muros da universidade, nas trocas de experiências com o outro. Como sabemos, todos locais tem múltiplas potencialidades próprias e especificas para educar um indivíduo, reforço esse pensamento com Brandão quando nos diz que:

A educação existe onde não há a escola e por toda parte podem haver redes e estruturas sociais de transferência de saber de uma geração a outra, onde ainda não foi sequer criada a sombra de algum modelo de ensino formal e centralizado (BRANDÃO, 1981. p. 13).

Em um terreiro de candomblé não é diferente, o ato educacional das crianças, jovens e adultos, ou seja de todos que encontram-se inserido nesse mesmo contexto, acontece nas trocas de interações e experiências, no convívio diário de suas práticas, na transferência de saberes.

Para compreender esse processo educacional não formal que acontece nos espaços de um terreiro de candomblé, realizei entrevistas com quatro adeptos da religião de matriz africana e que foram crianças de candomblé, a 


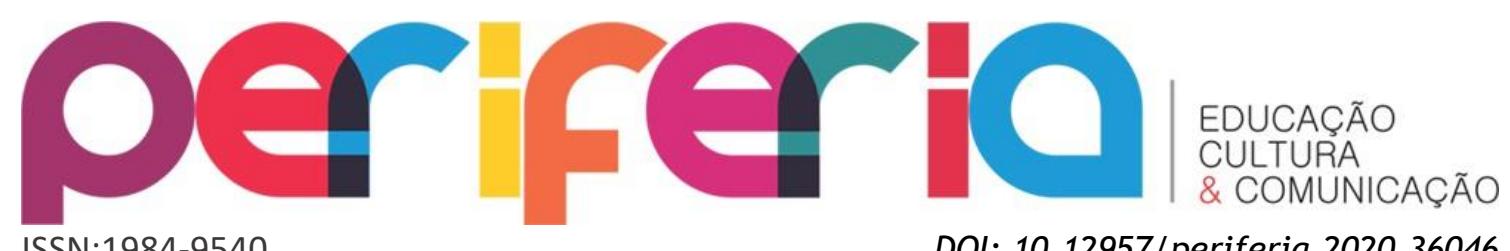

DOI: 10.12957/periferia.2020.36046 partir das informações coletadas selecionei alguns trechos da conversa para que pudessem fazer uma reflexão sobre a memória educativa de cada um sobre o convívio no terreiro.

Com base em relatos dos mais velhos que compõe um terreiro de candomblé, é fácil identificar que passaram por uma série de preconceitos, que se propaga até os dias atuais em diversos espaços que se encontrem, mas poucos foram afetados isso por que, muitos moravam dentro de um terreiro matriz e recebiam ensinamentos para valorizar a sua cultura, e a respeitar o outro.

Dos entrevistados, o Tata Rya Nkise ${ }^{7}$ Nhunkabukila $^{8}$, continua esse trabalho de ensinamentos dentro do seu próprio terreiro, e no seu relato nos fala como foi decisivo em sua vida todos os ensinamentos recebidos para a formação da sua identidade negra,

Falar de educação não formal implica em falar de uma educação desprendida sem limites e sem muros. A educação transmitida dentro do terreiro em seus espaços não escolares, preparando as crianças para o convívio dentro e fora do terreiro a importância desses ensinamentos é pontuado por Vanda (2010, p.55) quando diz que "ensinamentos transmitidos dos terreiros na comunidade vão colocar o outro dentro do seu odu, dentro da sua própria sina, do seu caminho, do seu jeito de ser no mundo".

Para educar as crianças, o mais velho utiliza símbolos, imagens, representações, rituais, as transmissões desses ensinamentos são valorizadas pela oralidade, seguindo como modelo a reprodução. Nesse momento, as crianças aprendem ouvindo e observando os mais velhos, repetindo na pratica, esse meio de aprendizado é defendido por Caputo (2012, p. 157) afirma que "é na experiência que se aprende e se ensina".

Lembro-me quando criança que entre uma quizomba (festa), ou qualquer acontecimento que era realizado nos espaços do terreiro era tudo muito rico, de ensinamentos constantes e diários, que me direcionava para a construção da

\footnotetext{
7 Tata Rya Nkise significa Pai de santo.

${ }^{8}$ Nhunkabukila- Aventureiro
} 


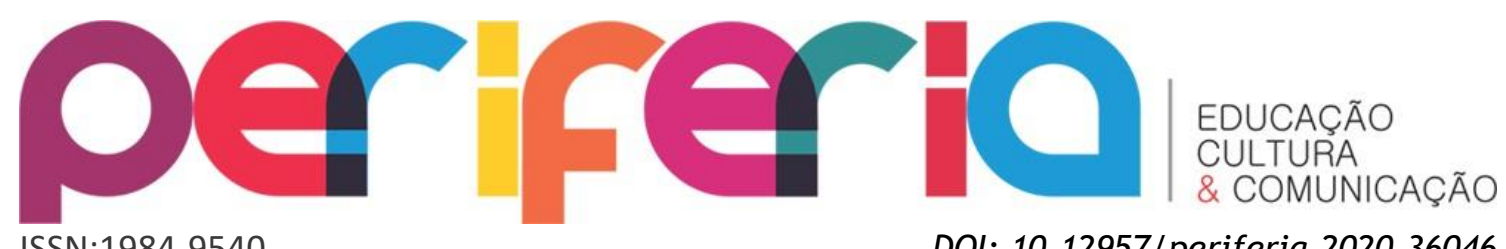

ISSN:1984-9540

DOI: $10.12957 /$ periferia.2020.36046 identidade negra, e aos poucos ia internalizando os ensinamentos e responsabilidades que eram atribuídas.

Isso mesmo desde muito cedo dentro de um terreiro aprendemos a ter responsabilidade, e em meio as brincadeiras tínhamos obrigações a cumprir como: colar as bandeirolas para as festas, cortadas em papel seda e ao longo do terreiro se amarravam um cordão de uma extensão a outra, passava uma cola feita com uma mistura de água e goma, e por horas ficávamos colando as bandeirolas que enfeitavam todo o local. Entre uma bandeira e outra colada sempre tínhamos a companhia de um mais velho que nos ensinava cantigas ou contando algum mito.

Essas responsabilidades faz parte da doutrina e ensinamentos de um terreiro. Na religião de matriz africana com respaldo na cultura Angola existe uma escala hierárquica que direciona todo o povo, que subdivide-se em Tatas, Kotas, Nkimba9 , e os cargos de maior grau hierárquico que é Tata ou Nengua de Nkise, essas denominações se trata da nação Angola Muxicongo.

É na infância que as crianças de terreiros de candomblé estabelecem vínculo com as relações hierárquicas de respeito e obediência aos mais velhos, nos terreiros a hora de ser criança também é respeitado, é o momento em que cada criança imagina e reproduz algo ou uma cena que ficou registrada em sua mente, quase sempre ações de um mais velho, ou de algum Nkise, é o momento em que disputam entre elas toques, cânticos e danças.

Éramos um grupo entre 7 a 8 crianças que moravam no terreiro com 0 olhar bem atento para tudo que acontecia em uma quizomba (festa), para não perder nenhum detalhe, no outro dia reproduzíamos tudo, claro que até onde conseguíamos acompanhar, por que não demorava muito e já estávamos exaustos e caiamos em um sono profundo.

E no dia seguinte nos reuníamos, embaixo de uma arvore, um local que chamávamos de secreto mais que todos mais velhos sabiam onde estávamos, mesmo por que era impossível não escutar o som das nossas latas de azeite de dendê, como o terreiro estava em constantes atividades então comprava-se

\footnotetext{
${ }^{9}$ Nkimbas- filhos de santo da casa.
} 


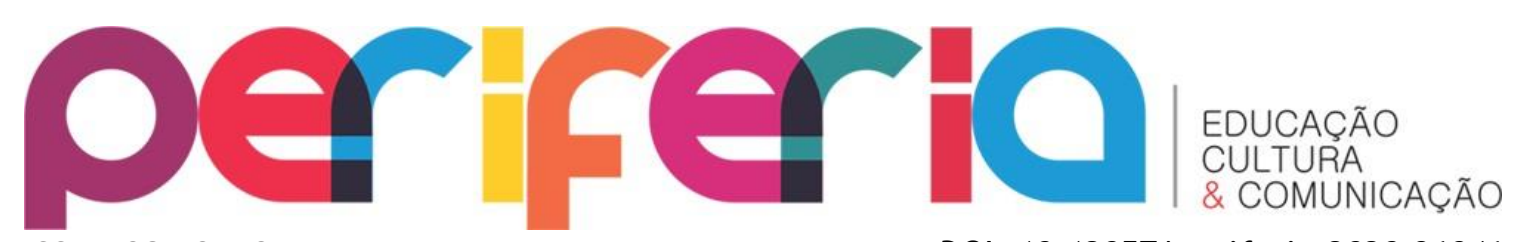

ISSN:1984-9540

DOI: $10.12957 /$ periferia.2020.36046 sempre as latas de azeite de dendê, e logo que esvaziava, pegávamos para ser a representação do nosso engoma.

Nesse espaço reproduzíamos quase tudo que conseguíamos guardar na memória, era um processo de repetições, nesse direcionamento sigo costurando os retalhos da minha memória, e relatos dos remanescentes que conviveram nesse espaço, e em todo processo de identidade constituído dentro de um terreiro de candomblé.

\section{Criança de Terreiro}

Criança de Terreiro defino como toda criança que convive nos espaços de um terreiro de candomblé, sendo criada e educada, que recebe ensinamentos constantes de todas as pessoas mais velhas que compõem a casa, essas crianças seguem todos os passos ensinados pelo mais velho, um passo de repetições de todas as ações presenciadas e ensinadas, para reforçar esse entendimento Caputo (2012) diz que: "As crianças de candomblé desempenham funções como os adultos. Muitas são iniciadas e algumas, depois de um longo aprendizado, estão preparadas para receber os Orixás" (p. 66).

Muitas crianças inicia o seu convívio dentro dos terreiros de candomblé com a sua família que ao fazer parte da religião de matriz africana leva seus filhos que aos poucos vão sendo preparados para assumirem cada um à sua responsabilidade com a religião. Essa é uma das obrigações dos mais velhos do terreiro que é transmitir os ensinamentos para os mais novos, na hierarquia da religião de matriz africana. Define-se mais velhos todas as pessoas iniciadas no santo, conta-se não apenas a idade cronológica mais também o tempo de iniciação no santo. Iniciação dentro do candomblé significa nascer para o santo.

A religião de matriz africana, é uma religião baseada na hierarquia, em que devemos seguir toda uma doutrina e algumas regras, os ensinamentos são transmitidos gradativamente, só se aprende o que é permitido aprender, existe um ensinamento que é universal na religião que é o respeito ao próximo, as 


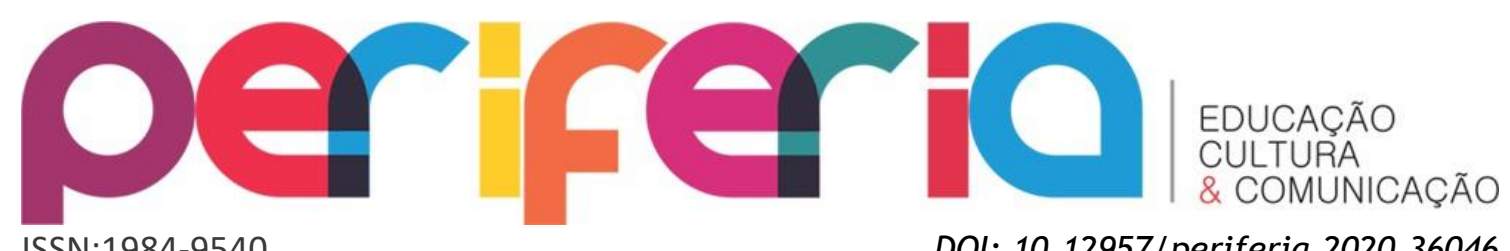

DOI: $10.12957 /$ periferia. 2020.36046 crianças desenvolve seu aprendizado cantando, dançando, louvando os Nkises ${ }^{10}$, as forças da natureza, e aprendem a conviver com a sua cultura. Dentro das casas de Axé a nossa cultura é enaltecida em todos os momentos, e nesse espaço independente da sua cor, do seu padrão social, ao pisar em um terreiro deve seguir a hierarquia que ali é imposta, com os ensinamentos as crianças tem seus valores étnicos e culturais valorizados e que aos poucos vão sendo internalizados. "No candomblé o conhecimento é transmitido oralmente em estágios específicos para cada filho (a). Estes ensinamentos e fundamentos são o marco principal, da diferença, delimitam o lugar do indivíduo na estrutura religiosa e sua distância frente a outros" (LIMA, 2005.p.60).

O discernimento desses ensinamentos continua no terreiro estudado, na Manso Gongombira, as crianças que convivem nesse espaço aprendem a se identificarem como afro descendentes e logo se apropriam da sua identidade como criança negra e candomblecistas, isso por que o maior exemplo encontrase dentro da própria casa em que a maioria dos mais velhos que compõe a família Manso também foram crianças de candomblé, em que muitos nasceram e moraram por muitos anos no espaço de um terreiro matriz o qual contribuiu para a nossa formação.

As crianças são respeitadas e tem prioridade em muitas ações dentro de um terreiro, a exemplo disso é na hora das refeições. Dentro da linha de hierarquia as refeições são realizadas do mais velho para o mais novo, a exceção das crianças que são as primeiras a realizarem as refeições, também um momento de aprendizado.

Em fila seguíamos para a cozinha para pegar nosso prato de comida, depois éramos guiados por um mais velho, que nos conduza para baixo de uma gameleira, uma arvore sagrada que ficava dentro de um assentamento do Nkise Tempo, sentados realizávamos nossas refeições. Em todo este cotidiano ouvíamos atentamente alguns ensinamentos, afirmação indenitária era reforçada por todos os mais velhos, que percorriam e percorrem o bairro da Mata Escura trajadas com suas indumentárias religiosas.

\footnotetext{
${ }^{10}$ Nkises- divindades.
} 


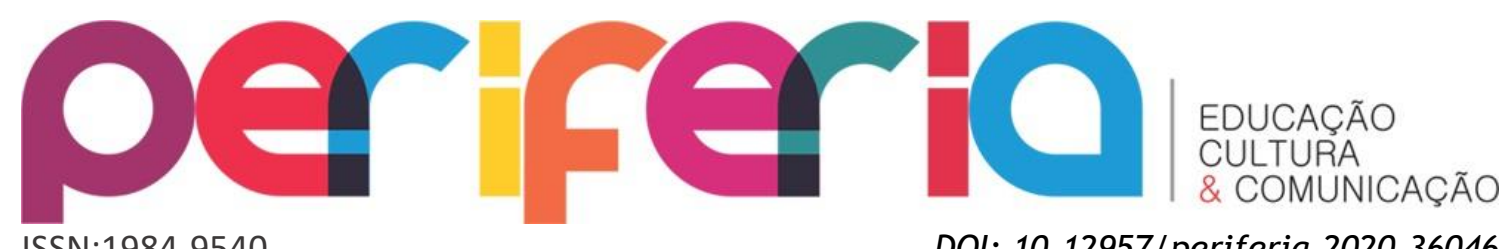

ISSN:1984-9540

DOI: $10.12957 /$ periferia.2020.36046

Sempre que nos reunimos as lembranças são reativadas e recontadas para todos. Hoje seguimos os legados e a forma de transmitir os conhecimentos se mantem que é através da oralidade, garantindo no outro o desenvolvimento intelectual, social e humanitário.

O sacerdote da manso Gongombira, da mesma forma que eu, fomos criados em um dos maiores terreiros de Salvador. Hoje tombado e com cem anos resistência, o terreiro do Bate Folha, localizado no bairro da Mata Escura. Demonstra seu posicionamento para que todos possam seguir seus passos, anda todo o bairro com a sua indumentária africana, vai ao supermercado segue vestido e com suas guias em todos os espaços, mostrando, principalmente as crianças, a importância de valorizar suas heranças e não ter vergonha. Ao passar pela rua é cumprimentado pelas crianças da redondeza, em que erguem as mãos e em sinal de respeito ao mais velho pedem a benção, algumas dessas crianças da comunidade convivem em ambos os terreiros o matriz e a Manso Gongombira e nesses espaços que aprenderam a valorizar e respeitar os mais velhos.

Identificar como as crianças que convivem no terreiro tem sua identidade étnico racial formada é algo muito visível. Um dos exemplos é Ítalo de 3 anos de idade (Fig. 1), que ao chegar no terreiro com seu pai, fica ansioso para tomar o banho de ervas, que ele chama de "banho que não se enxuga", isso porque não é permitido enxugar-se após o banho de ervas, deve secar no corpo, diz os antigos que é uma forma das energias das folhas penetrar mais rapidamente os nossos poros, e nos proteger de tudo de ruim que possa acontecer. Após o banho, coloca a sua roupa de ração ${ }^{11}$ tão alva que chega doer os olhos e sua guia no pescoço não pode faltar.

\footnotetext{
${ }^{11}$ Roupa de ração- roupas usadas no dia a dia.
} 

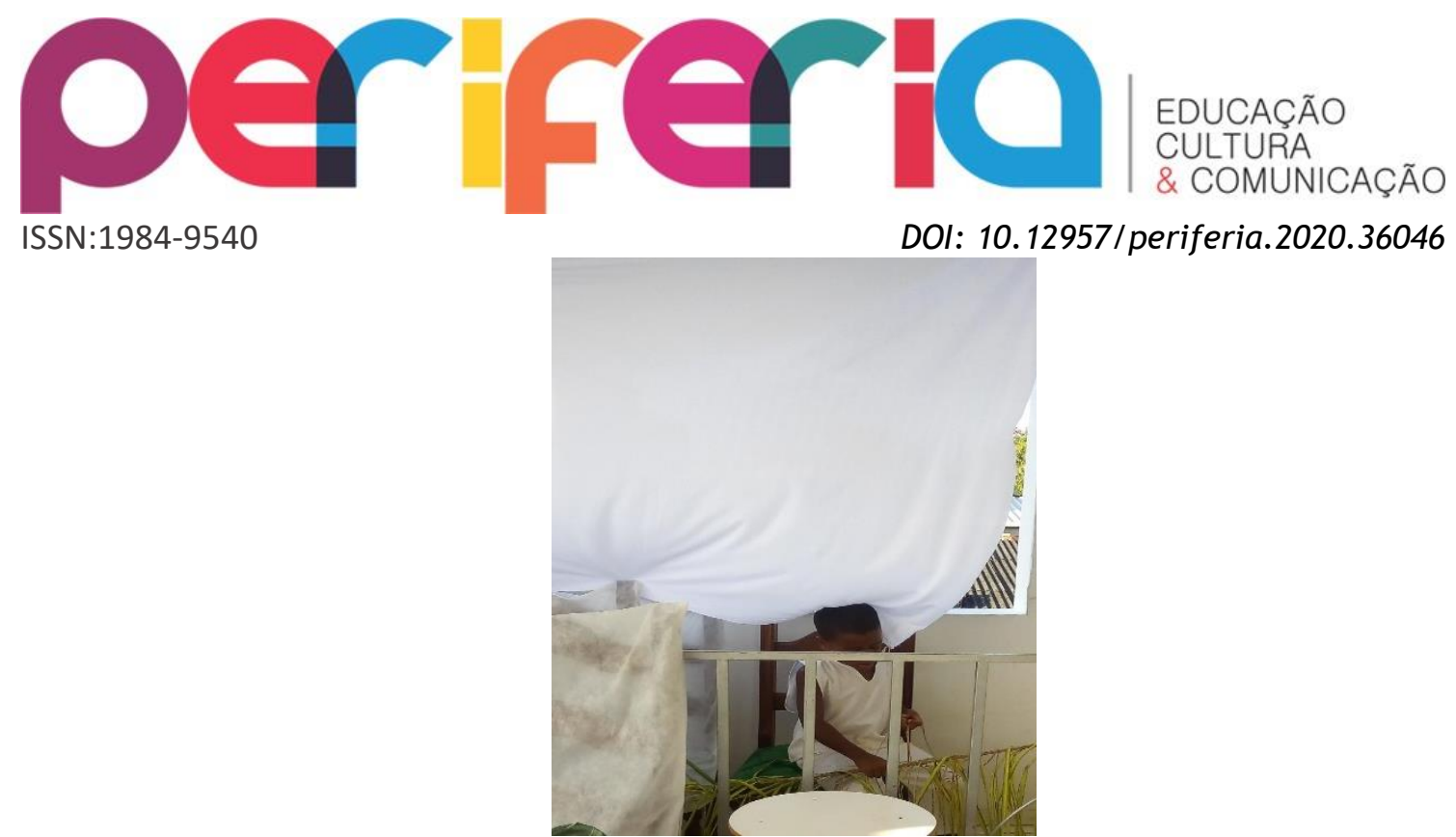

Figura 1 - Criança de Terreiro: Ítalo. Fonte: Arquivo da Autora (2018).

Podemos perceber a importância que se tem em nos despir desses antigos preconceitos e estereótipos para compreender a importância cultural de cada povo, cada grupo cultural tem a sua identidade própria, com hábitos, costumes, crenças como afirma Vanda Machado (2002, p. 30): "Tudo que se vive no terreiro dá identidade ao grupo, estabelecendo princípios que visam sempre a melhor relação desse indivíduo com o meio".

Ítalo em pouco tempo já está entrosado com os mais velhos e começa a reproduzir tudo que the fora ensinado. Vai a mata em busca de folhas para concretização do sagrado, quando vai começar uma obrigação logo sai correndo para pegar seu engoma que ganhou para que possa ir treinando, se posiciona e começa a tocar. Através da imagem abaixo (Fig. 2) podemos observar como uma criança que convive em terreiro de candomblé internaliza os ensinamentos na convivência diária com a religião. 


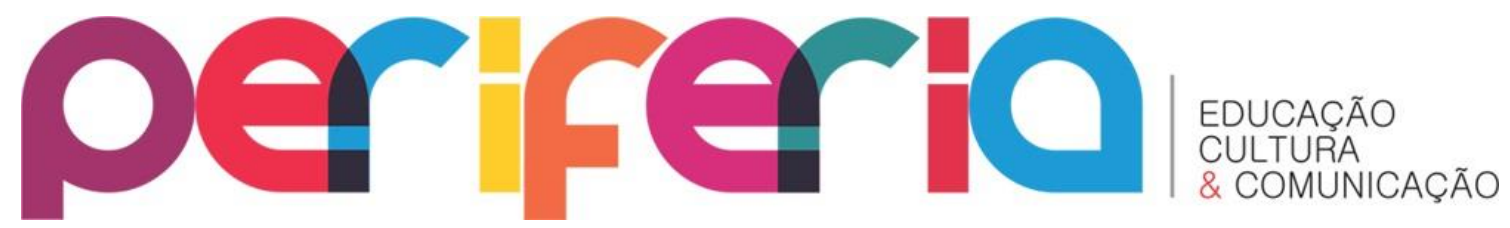

ISSN:1984-9540

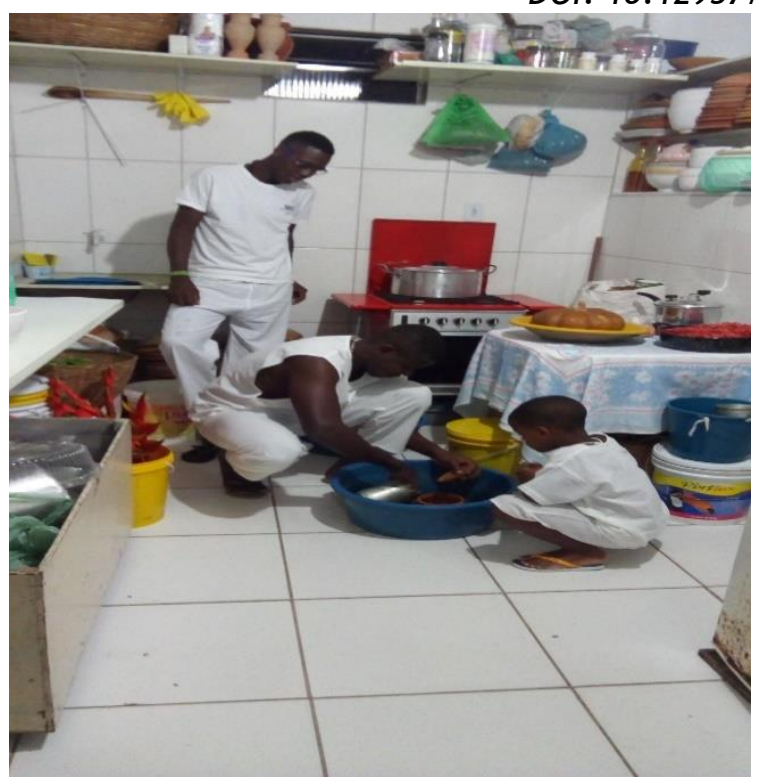

Figura 2 - Criança de Terreiro: Ítalo. Fonte: Arquivo da Autora (2018).

Na imagem Ítalo de 03 anos de idade, observa os ensinamentos que está sendo transmitido por seus mais velhos. Entre um ritual e outro, as crianças são ensinadas para que desempenhem funções exercidas pelos mais velhos, as crianças prestam bastante atenção nos ensinamentos e mais tarde irão reproduzir. Acima é um ritual de lavagem de objetos que serão utilizados em um ritual, antes de usar.

Qualquer objeto nunca utilizado, deve-se ser lavados com banho de ervas, é um processo de purificação. Aprendemos muito com o olhar, na observação constate das atividades realizadas dentro de uma roça de candomblé.

\section{Pedagogias do terreiro: oralidade e memória}

Durante anos tentaram nos silenciar, nas mais diversas formas de punições, não era permitido cantar, dançar, louvar, tocar nossos engomas. Tudo que era realizado pelo negro era considerado um afronte pela classe dominante que predomina por longos anos. A única coisa que não conseguiram retirar de nosso povo foi a força da oralidade, nem silenciar a nossa memória que prevalece viva até os dias atuais. 


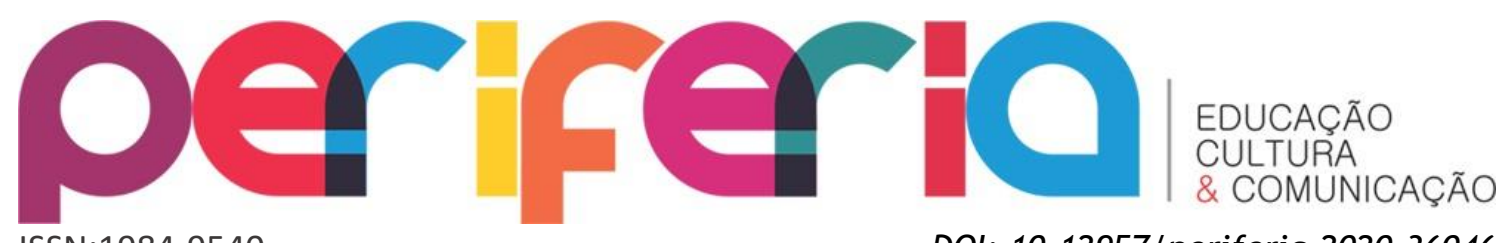

ISSN:1984-9540

DOI: $10.12957 /$ periferia.2020.36046

São diversas as tentativas de incutir no povo negro, uma cultura única, podemos presenciar em diversos lugares principalmente nos espaços escolares. $\mathrm{Na}$ construção desse tópico conto com a rememoração das lembranças que vivi juntamente com os entrevistados desse trabalho nos espaços do terreiro no qual fui criada, e hoje repetimos para as nossas crianças e adultos mais "novos" tudo que aprendemos através da oralidade e das memórias.

Na religião de matriz africana a oralidade e a memória são elementos integrantes para a constituição da identidade negra candomblecista fazem parte da cultura do nosso povo, é tradição nos terreiros transmitir os ensinamentos através da tradição oral que é uma forma encontrada de preservar a cultura afro, que é definida por Vanda Machado (2002, p. 29) como uma "característica da educação que inicia o indivíduo, gradativamente, na sabedoria do candomblé e na sua simbologia que é eminentemente contextual".

Esse contexto se baseia em contos, mitos, rezas, cânticos e representações de objetos e apetrechos constituinte da nossa cultura. Tínhamos momentos de brincar e momentos de aprendizagens, existiam mitos para todo tipo de ensinamentos, era uma pratica comum a contação de histórias e mitos sobre diversas situações, em variados momentos esse ato de contar mito vem de tradição:

Contar mitos em muitos lugares na África, faz parte do jeito de educar a criança que, mesmo antes de ir para a escola, aprende as histórias da sua comunidade, os acontecimentos passados, valorizando-os como novidade. Os mitos de matriz cultural evidenciam valores de convivência e solidariedade (MACHADO, 2002, p.4).

Entre um mito e outro, lembro-me de um que era contado diversas vezes, o mito das frutas sagrados, como morávamos em um grande espaço, árvores frutíferas não faltavam, nem tão pouco variedades, sempre éramos ensinados, que para sempre termos fartura, toda primeira safra de um arvore deveria deixar seu fruto cair naturalmente, e ser entre ao assentamento do Nkise mais velho da casa, que era o Nkise Nzazi, considerado o Nkise da justiça. 


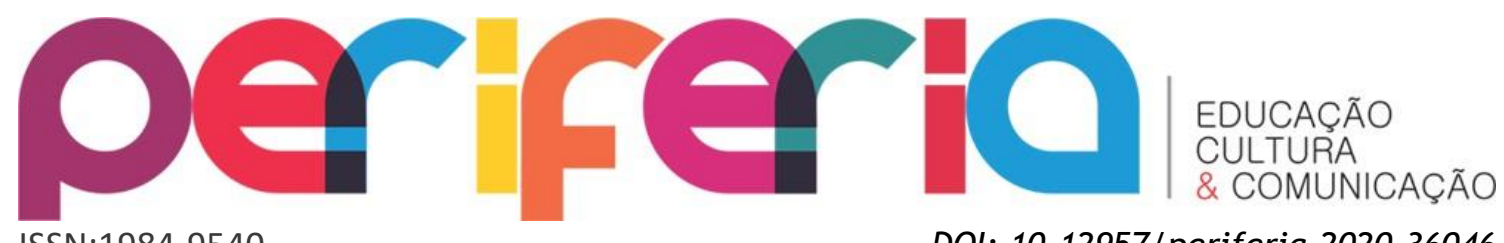

ISSN:1984-9540

DOI: $10.12957 /$ periferia. 2020.36046

Com o tempo compreendi que esse mito nada mais era do que uma forma

de nos ensinar a importância de não nos apropriarmos das coisas alheias, e a respeitar sempre o mais velho, cada arvore frutífera ao dar seu primeiro fruto, o mesmo deveria amadurecer e cair naturalmente, não poderia ser retirado, quem encontra-se a fruta caída tinha por obrigação de entregar ao sacerdote que orientava a todos. A fruta passava por um processo que chamamos de descansar, em que era lavada em água correte, em seguida banhada com ervas e ficava em um local com sombra descansando, mais tarde o sacerdote se dirigia ao assentamento (local de consagração do Nkise) e entregava aos seus pés.

Uma demonstração de obediência e doutrina que regia a todos na casa, só depois desse ritual as frutas estavam liberadas para consumo. Compreendo essa ação como forma de ensinar a proteger a natureza e saber esperar o tempo certo de cada elemento vivo.

Contam os mais velhos que ofertando o primeiro fruto ao Nkise, o mesmo nunca deixaria faltar um alimento em nossa mesa e a arvore se tornava abundante em seus frutos durante todo ano. Esse ritual era mantido e seguido, e como sabemos criança tem curiosidade por tudo que soa proibido e muitas vezes não obedecíamos, a curiosidade e desejo pelo proibido era mais forte, mais essa desobediência não passava sem um tipo de punição, sempre tinha alguém que caia doente ou tinha uma forte dor de barriga.

E assim é a cultura afro, com mitos que ensinam a preservar o meio ambiente, a natureza, os animais, as ervas, os mais velhos, a conhecerem sobre nossos Nkises. A nossa cultura vivencia um ciclo em que hoje você aprende, amanhã você ensina, hoje você é mais novo, amanhã se torna um mais velho e continuamos a aprender sempre. Mesmo depois de adulta escuto atentamente histórias e mitos hoje muitas contadas em sua maioria pela minha mãe.

A palavra dita por um mais velho é sinal de obediência, tudo tem um intuito de ensino na hierarquia do candomblé. A exemplificar o que relato um mais nunca deve se aproximar de um mais velho, sem que antes peça permissão e seja autorizado.

Periferia, v. 12, n. 3, p. 268-301, set./dez. 2020 


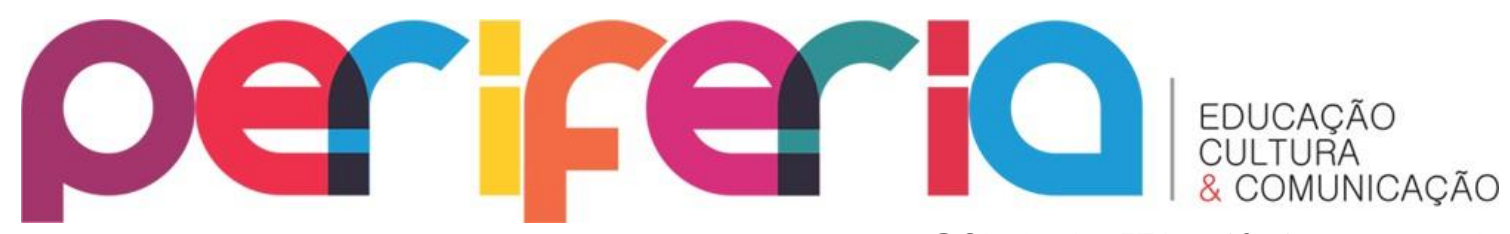

ISSN:1984-9540

DOI: $10.12957 /$ periferia.2020.36046

Ao amanhecer do dia quem cumprimenta primeiro pedindo a benção é sempre o mais novo, o qual se direciona a seu mais velho. 0 respeito ao mais velho é outro valor enaltecido dentro de um terreiro, com o uso da oralidade a nossa identidade aos poucos vai sendo fortalecida e firmada.

Como morávamos nos espaços do terreiro, ele se tornou a nossa primeira escola, onde aprendíamos no convívio e aos poucos éramos preparados para coexistir fora dos muros do terreiro. 0 aprendizado era diversificado e de forma aleatória, mas sempre com uma intencionalidade pedagógica. Nesse espaço que aprendi as primeiras letras, aprendi a ler e a escrever com os professores graduados na experiência de vida.

Um local que sempre esteja renovando, e que transfira sua força para a criança, e que dure por longos anos, assim foi feito por minha mãe, assim que nasci enterrou o meu umbigo em uma arvore sagrada conhecida como Gameleira, uma arvore muito respeitada na nossa cultura, tem por descrição longas raízes expostas, folhas largas e brilhosa, essa arvore nunca morre, sempre se renova, nas suas raízes brotam mudas que aos poucos ocupa todo o espaço da matriarca, e graças a essa arvore que transmitiu toda sua força e nunca permitiu que fraquejasse nos primeiros obstáculos encontrados na vida, como dizem os antigos "Enverga mais não quebra".

Por isso hoje no papel de educadora que me encontro tenho como obrigação de inventar e reinventar diversas formas para que as crianças negras possam ver refletida sua imagem e se identifique de forma positiva dentro da sala de aula que me encontro. Foi graças a cultura afro que superei o racismo, e hoje sou uma mulher negra, pedagoga, da religião de matriz africana e emponderada. 


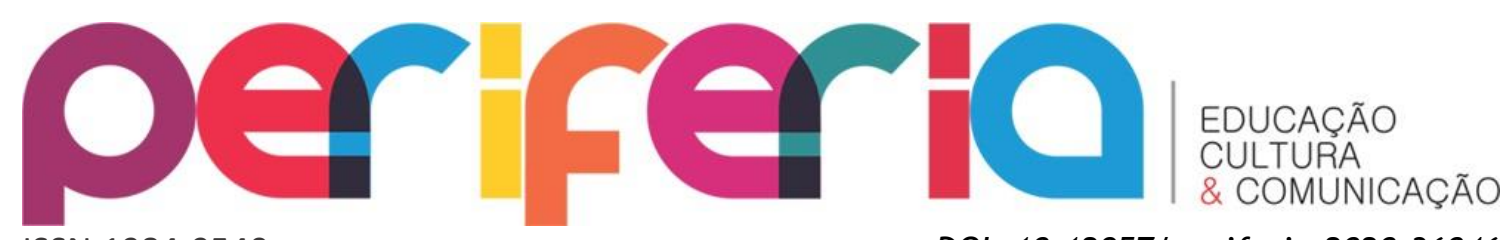

ISSN:1984-9540

DOI: $10.12957 /$ periferia.2020.36046

Superação do racismo

Superar o racismo é um processo contínuo, realizado internamente que envolve compreender a relação que tenho comigo mesma, com o outro e com as minhas raízes. Uma busca constante para tentar desvendar o que leva o outro a realizar ações perversas que machuca, fere profundamente deixando marcas que demoraram a cicatrizar, a maneira encontrada para a auto defesa seguia o mesmo nivelamento recebido, era um ato de ação e reação que acaba ferindo o outro também, para entendermos tais atitudes concretizada por nos seres humanos, Paulo Freire (2001) destaca que: "não faz parte da natureza do ser humano a perversidade do racismo. Não somos racistas, tornamo-nos racista assim como podemos deixar de estar sendo racista".

$\mathrm{Na}$ necessidade de auto defesa e de firmamento muitas vezes somos obrigados a ultrapassar alguns ensinamentos, nada que hoje seja motivo de orgulho, nem tão pouco de vergonha mais sim de reflexão crítica, sobre as nossas ações e a não perpetuação do racismo.

Para falar sobre o processo de superação do racismo, é necessário reativar lembranças do período de formação educacional, até a firmação enquanto mulher negra e afrodescendente. Esse processo de produção e construção da identidade negra até a superação do racismo, durou por longos anos, ao ser inserida nesse espaço educacional formal.

As primeiras letras que conseguir escrever, foi com o tata Rya Nkise NHUNKABUKILA, que na época um adolescente que frequentava a escola formal, isso na minha geração, por que na geração de minha mãe que também foi criada em terreiro de candomblé, todo seu processo de alfabetização realizou-se por uma mais velha do terreiro.

Para que entendam esse processo de alfabetização, preciso delimitar que a minha mãe nasceu em 1952, nessa época era primordial ensinar as mulheres os fazeres domésticos. Com a evolução do mundo hoje os ensinamentos dentro de um terreiro se modificou, esses fazeres domésticos não é mais prioridade, as crianças são ensinadas a irem em busca da evolução plena como ser humano. 


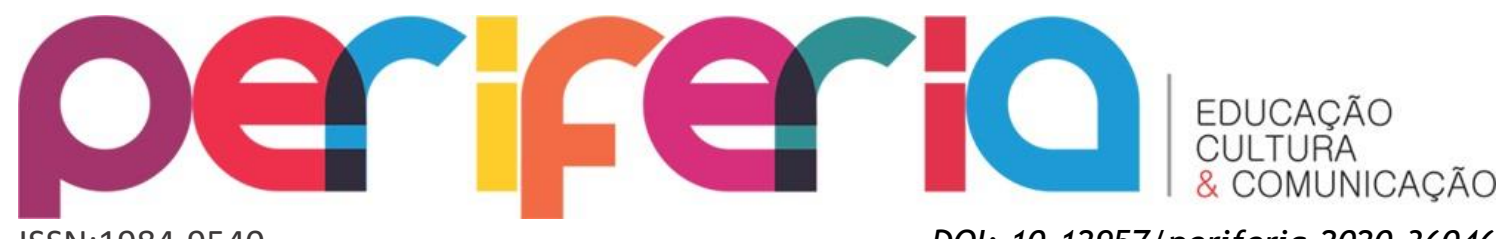

ISSN:1984-9540

DOI: $10.12957 /$ periferia.2020.36046

Lembro-me como hoje no primeiro dia que tive contato com o espaço escolar formal, era tudo muito diferente do que estava habituada, o espaço, as pessoas, os meios utilizados para o ensinamento e a maneira robótica que eram repetidos os ensinamentos, existia uma ordem de arrumação da sala, um posicionamento a seguir, logo eu que estava acostumada a sentar no chão, no banco, em qualquer lugar que me sentisse confortável, foi difícil o processo de adaptação na escola.

Não foi fácil esse processo de ser introduzida em um espaço educacional formal, confesso que em alguns momentos foi doloroso, ter que me adaptar era necessário, afinal de contas a "estranha no ninho" era eu, aos poucos nos relatos sobre a cultura negra fui percebendo o quanto essa cultura tinha sido enraizada com heranças que foram negativadas pela sociedade.

Por conta dessa negatividade histórica que acompanha nossas origens sofri muitas discriminações, racismos e preconceitos, devido a ocultação da nossa história que é muito bem explicado por Munanga (2005) quando diz em sua obra que:

A invisibilidade e recalque dos valores históricos e culturais de um povo, bem a inferiorização de seus atributos adscritivos, através de estereótipos, conduz esse povo, na maioria das vezes, a desenvolver comportamentos de auto rejeição, resultando em rejeição e negação dos seus valores culturais e em preferência pela estética e valores culturais dos grupos sociais valorizados nas representações (MUNANGA, 2005, p.22).

Ao abrir um livro didático, facilmente nos deparamos com representações desse grupo social descrito por Munanga, sempre com supervalorização e enaltecimento, julgo importante conhecer e trabalhar nas salas de aulas, as múltiplas histórias culturais e social que compõe o nosso povo as nossas origens, por não termos a oportunidade e direito de conhecer sobre a história do outro que muitas crianças negras sofrem nesse espaço formal de educação, discriminações, racismo e preconceitos que para melhor entendimento sinto a necessidade de defini-las.

Sentir na pele cada peso do racismo, nas mais diversas formas, fui discriminada, oprimida por uma classe que se julga superior, auto avaliada em 


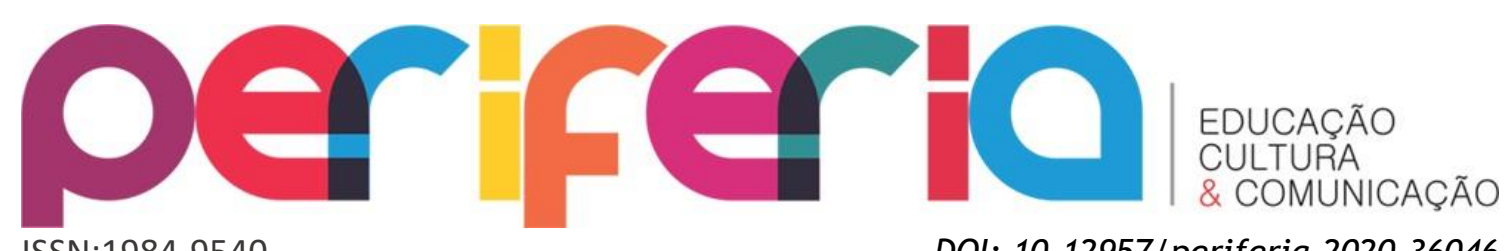

ISSN:1984-9540

DOI: $10.12957 /$ periferia.2020.36046 vários pré julgamentos, na escola não foi diferente, com suas ações de reprodução e perpetuação do racismo, preconceito e discriminação induz a criança negra a rejeitar as suas origens.

Nesse espaço assim que fui inserida, aos poucos sentia o peso em cada olhar, e quando chegava o momento de se apresentar a turma, ai era a hora em que muitas vezes sentir vontade de sair da sala, quando a pergunta lançada: você é de religião? A maioria, se não quase toda, responder católico, outros cristão e nenhum era da religião de matriz africana. Essa pergunta já era uma avaliação? Ficava com os pensamentos inquietos essas ações repetidas por diversos profissionais que cruzavam meus caminhos, me sentia tão diferente e muitas vezes repetia a resposta de outros, negava as minhas origens e assim foi por todo ensino fundamental.

Tinha meu pensamento e identidade étnico cultural formada, mais não me sentia preparada para enfrentar o mundo, percebi que se firmar como negra, afrodescendente não é algo fácil. E assim foi mais uma etapa no ensino médio.

Então chego ao ensino superior, outra trilha do caminho que apenas estava começando, e posso afirmar que a introdução no ensino superior foi algo de positivo que posso pontuar no trajeto educacional formal, nesse espaço mesmo que em pequena quantidade abriram se um leque de possibilidades de firmação, um ou outro professor já falava da cultura afro de forma mais branda, na maneira de entoar as palavras sentia a leveza e logo no segundo semestre ao surgir o convite do professor de antropologia da educação em visitarmos o museu afro. Observando do meu canto pude ver que a proposta foi muito bem aceita, muitos sentiam curiosidade, outros diziam conhecer ou ter parentes próximos que era da religião, pela primeira vez em todo percurso educacional pude me identificar, pude ser representada, o professor tinha propriedade do que falava, como falava e para quem falava, em alguns momentos da aula, parecia estar no meu espaço de origem e aos poucos aquela aula ia me deixando à vontade e sem perceber fui contribuindo até que tive que fazer uma apresentação formal para toda a classe, falar de onde vinha, das minhas origens e de forma breve minha história, esse espaço, esse educador

Periferia, v. 12, n. 3, p. 268-301, set./dez. 2020 


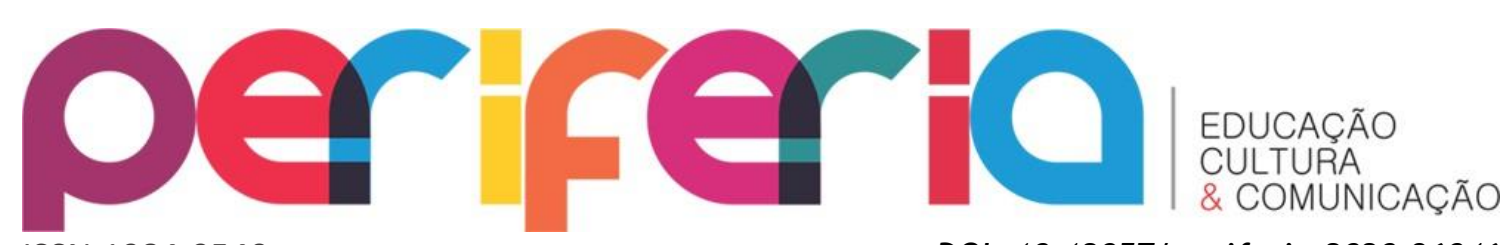

ISSN:1984-9540

DOI: $10.12957 /$ periferia.2020.36046 propiciou meios para que me sentisse segura e emponderada como mulher negra, pedagoga e pertencente a religião de matriz africana.

E assim continuou ao ser apresentada ao componente curricular Metodologia do Ensino da Geografia em que apresenta para a sua primeira turma da Faculdade de Educação um ensino da geografia renovada que rompe com o modelo tradicional de ensino, incluindo em seu currículo a cultura africana e afro-brasileira, reforçando e explorando as potencialidades do povo negro e da sua cultura.

Com as experiências vividas no processo educacional, posso afirmar que o espaço escolar nega representatividades positivas do negro. É visível a dificuldade encontrada por muitos profissionais em trabalhar o ensino da História e Cultura da África, mesmo sendo obrigatório pela lei 10.639/03, muitos profissionais não são preparados para trabalhar com a diversidade existente, passei por essa problemática e hoje muitas crianças como eu passam pelo mesmo problema. A falta de preparo dos profissionais é definida por Munanga, quando diz que:

Alguns dentre nós não receberam na sua educação e formação
de cidadãos, de professores e educadores o necessário preparo
para lidar com o desafio que a problemática da convivência com
a diversidade e as manifestações de discriminação dela resulta-
das colocam quotidianamente na nossa vida profissional. Essa
falta de preparo, que devemos considerar como reflexo do
nosso mito de democracia racial, compromete, sem dúvida, o
objetivo fundamental da nossa missão no processo de formação
dos futuros cidadãos responsáveis de amanhã. Com efeito, sem
assumir nenhum complexo de culpa, não podemos esquecer que
somos produtos de uma educação eurocêntrica e que podemos,
em função desta, reproduzir consciente ou inconscientemente
os preconceitos que permeiam nossa sociedade (MUNANGA,
2005, p. 15).

Não quero aqui firmar a culpa sobre o espaço escolar, e sim que esse espaço é apenas o local em que se reproduz essa falta de preparo. É necessário reformular as metodologias de ensino, reformular o currículo, aperfeiçoamento do livro didático que represente o negro positivamente, trabalhar a auto estima não apenas das crianças negras, mais de todas as crianças seja ela negra, 


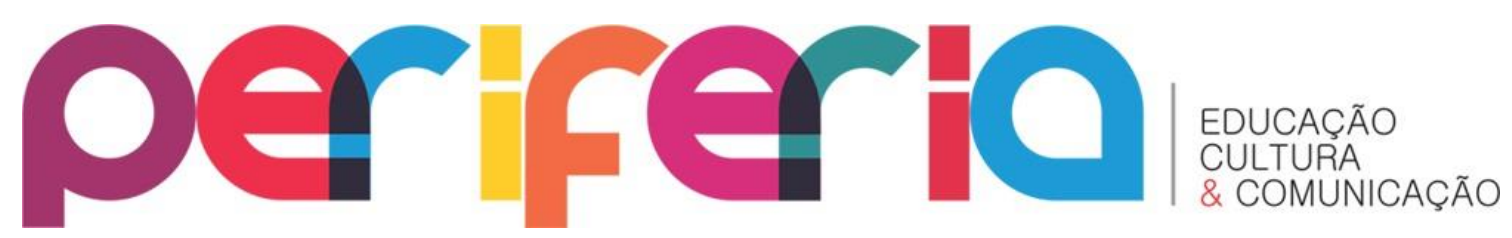

ISSN:1984-9540

DOI: $10.12957 /$ periferia.2020.36046 branca, que possam se identificar não apenas com a cultura afro mais sim com todas as culturas:

A credita-se que o negro vai desenvolver em si o sentimento da auto estima. Esse processo consiste em ações que promovam o resgate da cultura e história do negro, evidenciando seus heróis, eliminando definitivamente os estereótipos preconceituosos dos livros didáticos que evidenciam o negro sempre de forma inferior (CAMPOS Jr., 1999, p.73).

Como olhar para mim e negar as potencialidades educativas que existem dentro de um terreiro de candomblé, eu sou fruto desse espaço não educacional de ensino que possui um currículo invisível que é denominado por Munanga como:

Um currículo de transmissão dos valores, dos princípios de conduta e das normas de convívio, ou, numa palavra, dos padrões sócio- culturais inerentes à vida comunitária, de maneira informal e não explicita, permitindo uma afirmação positiva da identidade dos membros de um grupo social (MUNANGA 2005, p. 72).

Para compreendermos o processo de construção da identidade negra nas crianças que convivem nos espaços não formal de educação nos terreiros de candomblé, realizei entrevistas semiestruturadas com filhos de santo da casa estudada, que teve todo processo de ensino e aprendizagem dentro de um terreiro matriz, todos são negros e relatam a grande dificuldade encontrada para se firmarem como negro.

Os entrevistados se denominaram da religião de matriz africana, dois deles possuem ensino superior e os outros dois tem ensino médio completo, o processo de iniciação ao candomblé, se deu por algum familiar, o terreiro estudado a Manso Gongombira, regida pelo sacerdote Nhunkabukila, que teve seu ingresso nos espaços de um terreiro de Candomblé com três anos de idade, em 1974 a casa em que morava com seus pais desabou por conta de uma chuva muito forte, a casa era feita de taipa, sem ter para onde irem a família foi acolhida pelo terreiro do Bate Folha, localizado no bairro da Mata Escura.

Nhunkabukila sempre vivenciou dentro de um terreiro de candomblé, recebeu todos os ensinamentos e hoje é regente da Manso Gongombira, a casa

Periferia, v. 12, n. 3, p. 268-301, set./dez. 2020 


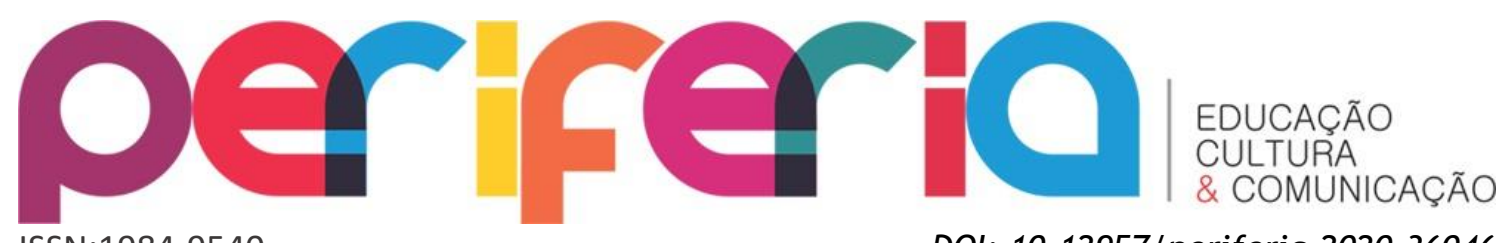

ISSN:1984-9540

DOI: $10.12957 /$ periferia.2020.36046 a qual pertenço e da continuidade no trabalho de conservação e perpetuação da cultura afro, é visível que a educação mantida através das gerações é capaz de favorecer na criança negra afro descendente a se auto reconhecerem em qualquer espaço que encontre inserida, como firma Nhunkabukila ao responder a pergunta: Como a religião de matriz africana favoreceu para a construção da sua identidade negra?

"A religião de matriz africana mostra o real sentido da igualdade entre as pessoas, fazendo valer a hierarquia $e$ mostrando que ser de religião de matriz africana, é saber da importância e valor a todo sofrimento e sacrifício vivenciado por cada mais velho".

(Nhunkabukila, 01/12/2017).

Todos os entrevistados se auto denominaram negro, que sofreram e sofrem diversos tipos de discriminações nos espaços formal de educação e em conversa afirmam que não foram afetados por qualquer atitude de preconceito e discriminação realizada pelo outro contra a sua cor ou religião.

Ao escutar atentamente cada resposta, observo a firmeza com que cada um relata, sobre não deixar ser influenciado, ao contrário por tudo que cada um passou serviu como uma base de alicerce, que os mantiveram firme e com mais desejo de lutar pelos seus direitos defendendo suas origens em todo espaço que se encontrem.

A firmeza escutada em cada fala, percebo como foi importante esse trabalho de construção da identidade negra dentro do terreiro, como cada um soube se firma em seus ensinamentos sem se deixar influenciar e hoje cada um sente a importância em continuar com esse trabalho com as crianças que hoje convivem nos espaços do terreiro.

Nesse momento apresento alguns trechos da entrevista que selecionei, trechos esses que firmam como o processo de ensino e aprendizagem dentro de um terreiro de candomblé foram essenciais para a sobrevivência e consolidação enquanto afrodescendentes, uma reflexão das memorias educativas de cada um.

Todos os entrevistados tiveram seu processo iniciatico educacional dentro de um terreiro de candomblé e mesmo criados em convívio com a 


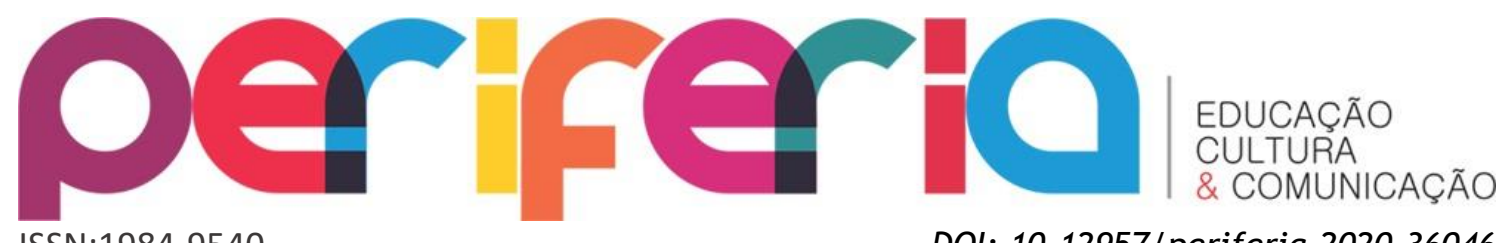

ISSN:1984-9540

DOI: $10.12957 /$ periferia.2020.36046 religião de matriz africana só foram iniciados na religião anos mais tarde, isso comprova que o processo de ensinamentos dentro da religião segue uma linha hierárquica e em estágios específicos como afirma Lima (2005):

No candomblé o conhecimento é transmitido oralmente em estágios específicos para cada filho (a). Estes ensinamentos e fundamentos são o marco principal, da diferença, delimitam o lugar do indivíduo na estrutura religiosa e sua distância frente a outros (LIMA,2005, p.60).

Foi graças a esses ensinamentos que ao perguntar a Nadja com 41 anos: como a religião de matriz africana favoreceu para a construção da sua identidade negra? ela responde com um tom de voz mais forte que "a religião de matriz africana, através dos ensinamentos transferidos agregou para que ela possa se sentir igual a todos" (Nadja 16/12/2017). Essa é uma das necessidades das crianças negras dentro de um espaço formal de educação, de se sentirem iguais, independente da sua religião, cor, raça, esse espaço democrático e igualitário de saberes e aprendizados encontramos nos terreiro de candomblé, nesse espaço todos são tratados com respeito, em que mantemos uma relação de valorização do ser humano.

Aos poucos vou percebendo como cada fala dos entrevistados dialogam com os referencias teóricos, podemos analisar esse processo de oralidade na obra de Caputo Educação nos Terreiros, a mesma pergunta foi realizada a Uadimuka em que responde:

A religião favoreceu na firmação do posicionamento auto afirmativo enquanto uma mulher negra diante das lutas diárias contra uma sociedade racista, machista e desigual, extremamente preconceituosa, principalmente para com os negro (Uadimuka 17/12/2017).

E hoje como educadora formada em letras, Uadimuka sente a necessidade de sempre criar rodas de diálogos com os seus educandos para possibilitar a desconstrução das falas que escuta diariamente em sala de aula referente a cultura afro brasileira. 


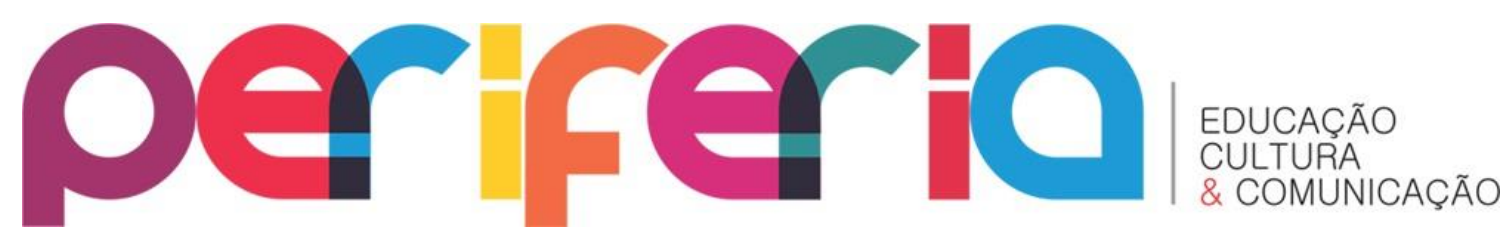

ISSN:1984-9540

DOI: $10.12957 /$ periferia.2020.36046

Essa preocupação em desconstruir estereótipos que encontra-se incutidos em nossa sociedade e auto reflete nas crianças, a entrevistada Uadimuka dialoga com Munanga, quando utiliza as ações recorrentes em sala de aula em um diálogo aberto e desconstrutivo.

Segui com a entrevista, ao realizar a pergunta aos entrevistados: Para você, o que é educação? Acha que existe educação ou formas de ensinamentos no terreiro? As respostas se interlaçam como um fio condutor, compreendi a indagação nos olhos após a pergunta lançada, percebi como cada olhar também me interrogava como se dissesse assim: e você aprendeu o que sabe hoje aonde? Então o deixei livres para responder:

Sim educação é tudo o que pode ser ofertado ao indivíduo, que the favoreça seu desenvolvimento intelectual, social $e$, sobretudo humanitário. Como todo e qualquer espaço, no qual se encontram e vivem as pessoas, afirmo que nestes espaços, os terreiros de Candomblé também contribuem para a formação do indivíduo ali presente. Dentro dos terreiros aprendemos a respeitar a natureza, valorizamos e respeitamos nossos mais velhos, e similarmente os nossos mais novos (Uadimuka, 17/12/2017).

Sim Como é sabido por todos, a religião Afrodescendente por ser fundada por negros da nossa matriz africana eram analfabetos, sendo assim, esses ensinamentos era todos orais, mas com o passar dos tempos chagando até nós, houve um grande avanço na questão do educar as pessoas em terreiros, $o$ advento da escrita e com ela a alfabetização possibilitou que adeptos do candomblé tivesse a oportunidade de alfabetizar $e$ até mesmo atualizar o conhecimento (Fukiavangila, 06/01/2018).

Existe sim, por que a educação é uma competência, que cabe em qualquer setor, e na religião tem a função de nos mostrar que independente da religião o que favorece é a percepção de quem somos iguais, e podemos conviver juntos numa mesma sociedade (Nadja, 16/12/2017).

Sim a educação é a base para ter conhecimentos do quanto somos capazes de enxergar o horizonte, e através do convívio com os mais velhos esse caminho se torna real (Nhunkabukila, 01/12/2017).

Através das falas podemos perceber como essa omissão em se trabalhar a diversidade cultural do nosso pais dentro das salas de aula, em especial a 


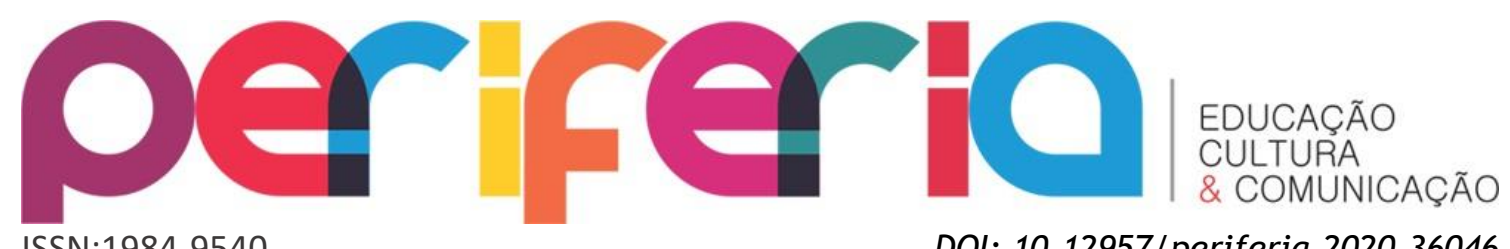

ISSN:1984-9540

DOI: $10.12957 /$ periferia.2020.36046 cultura afro pode trazer danos irreversível na vida de uma criança, como esse trabalho realizado nos terreiros de candomblé é importante, nesse ambiente as crianças são preparadas e educadas para saberem lhe dá com a diversidade, aprendem a valorizar a sua cor, a sua cultura o seu povo e com isso favorece na construção da identidade negra de cada criança que recebe esses ensinamentos.

\section{Conclusão}

A motivação para a realização desta produção textual teve como fio condutor todo o meu processo educacional vivido dentro e fora de um terreiro de candomblé. No início o tema não estava delimitado, mas não me identificava com nenhum outro, até que um professor na universidade me disse algo que me tocou: "Você não precisa falar do outro, pode e deve falar de você, da sua história". No início aquelas palavras martelaram meus pensamentos e aos poucos amadurecei e aceitei a ideia de falar sobre a minha vida.

Foi preciso um diálogo constante comigo mesma, para compreender que caminhos seguir, como seguir, e aos poucos cheguei à conclusão de que não era preciso falar de temas ao qual não me identificava, decide compartilhar a minha história de vida e todo processo educacional vivido dentro e fora dos terreiros de candomblé, seria apenas mais um desafio de vários ao qual fui desafiada por mim mesma, era no mínimo um tema diferenciado.

Não posso negar que aflições tomaram conta do meu coração, afinal de contas estava decidida a apresentar a minha história para muitas pessoas, e em um processo de conversa com o meu eu durante a noite cheguei à conclusão que era necessário defender as minhas origens, o meu povo, a minha cultura como uma criança que aprendeu a ler e a escrever com pessoas que não tinham nenhuma formação acadêmica e que utilizavam apenas como recurso educacional a oralidade e as memorias em um espaço educacional não formal.

O trabalho desenvolvido é de grande importância para compreendermos que o processo educacional existe em todos os espaços e nos terreiros de candomblé não é diferente, nesse ambiente não formal, são transmitidos

Periferia, v. 12, n. 3, p. 268-301, set./dez. 2020 


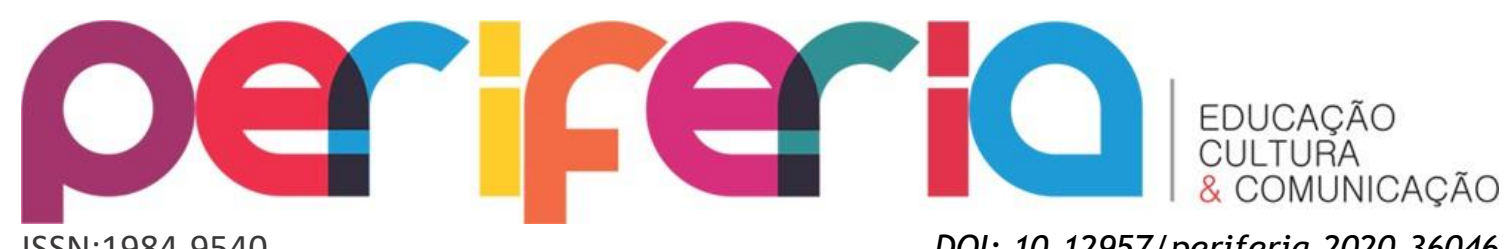

ISSN:1984-9540

DOI: $10.12957 /$ periferia.2020.36046 ensinamentos e valores que contribui para a construção e preservação da cultura negra nas crianças, através de estímulos constantes.

Nesse local vejo representado a verdadeira história e potencialidades do meu povo, algo não encontrado nos ambientes formais de educação e hoje como futura profissional da educação vejo refletida na minha imagem a necessidade de trabalhar e estimular o negro, a sentirem orgulho da sua cultura, do seu povo.

Não afirmo aqui que esse trabalho de enaltecer positivamente a cultura do negro dentro das salas de aula será algo fácil de se realizar, é notório que é um tema que causa muitas inquietações, gera conflitos, mas farei o meu trabalho, que é enaltecer a cultura afro-brasileira em qualquer espaço que encontre me inserida, chega de aceitar indicações do local que cabe o negro, o negro como qualquer outro ser humano cabe onde ele deseja estar.

Faz-se necessário o reconhecimento e valorização desses espaços não educacional que os terreiros de candomblé possuem como local de grandes valores e potencialidades educativas, procurei expandir meus conhecimentos relatando como os ensinamentos obtidos dentro de um terreiro de candomblé contribuíram no processo educacional da minha formação, como um ser crítico, capaz de se reconhecer e identificar as diversas formas de discriminações de forma mais consciente.

Espera-se que essa reflexão crítica aqui traduzida possa contribuir para a necessidade em reformular e ampliar a grade curricular do curso de graduação de Pedagogia da Universidade Federal da Bahia, que o ensino da cultura afrobrasileira, possa fazer parte da grade curricular dos componentes obrigatórios, e não mais optativo, e com isso oportunize os futuros profissionais da educação suporte didáticos necessários para que possam trabalhar nas escolas as leis 10.639 e 11.645 de modo que fortaleçam a identidade dos oprimidos que é a maioria da população negra.

Finalizo com uma certeza, que as infinitas situações conflituosas e difíceis ocorridas em todo meu processo educacional serviram como base para uma reflexão sobre a minha formação docente, e o mais importante saber como e o que devo fazer com tudo que aprendi.

Periferia, v. 12, n. 3, p. 268-301, set./dez. 2020 


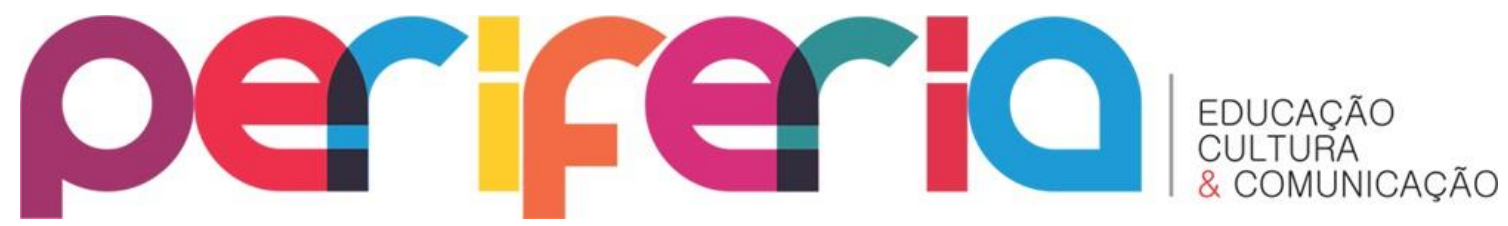

\section{REFERÊNCIAS}

CAPUTO, Stela Guedes. Educação nos Terreiros: Como a escola se relaciona com as crianças. FAPERJ. São Paulo. Gráfica Asschi 2012.

CAPUTO, S. G.; PASSOS, M. Cultura e conhecimento em terreiros de candomblé: lendo e conversando com mãe Beata de lemanjá. Currículo sem Fronteiras, v.7, n.2, pp.93-111, Jul./Dez 2007.

GOMES, Nilma Lino. Relações étnico-raciais, educação e descolonização dos currículos. Currículo sem Fronteiras, v. 12, p. 98-109, 2012. Disponível em: < www.curriculosemfronteiras.org/vol12iss1articles/gomes.htm > Acesso em: 15/02/ 2018.

MACHADO, Vanda da Silva. ILÊ AXÉ Vivencias e Invenções Pedagógica: As crianças do Opô Afonjá. Editora Edufba, Salvador 2002.

MACHADO, Vanda da Silva. Mitos afro-brasileiros e vivencias educacionais. Salvador 2005.

MUNANGA, Kabengele. Superando o racismo na Escola. Brasília 1986.

MUNANGA, Kabengele. Rediscutindo a Mestiçagem no Brasil: identidade nacional versus identidade negra. Belo Horizonte, Autêntica, 2008.

TAVARES, Ildásio, 1940- Nossos colonizadores africanos: presença e tradição negra na Bahia / Ildásio Tavares; [prefácio de Muniz Sodré] - 2. ed. - Salvador: EDUFBA 2009. $172 \mathrm{p}$. 